\title{
Functions of Exosomes and Microbial Extracellular Vesicles in Allergy and Contact and Delayed-Type Hypersensitivity
}

\author{
Katarzyna Nazimek ${ }^{a} \quad$ Krzysztof Bryniarskia $^{a} \quad$ Philip W. Askenase ${ }^{b}$

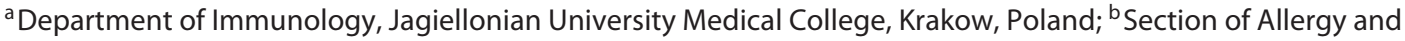 \\ Clinical Immunology, Department of Internal Medicine, Yale University School of Medicine, New Haven, Conn., USA
}

\author{
Key Words \\ Extracellular vesicles · Exosomes · Allergy · Asthma . \\ Delayed-type hypersensitivity · Contact hypersensitivity . \\ Contact dermatitis · Immunosuppression . \\ Immunoregulation
}

\begin{abstract}
Extracellular vesicles, such as exosomes, are newly recognized intercellular conveyors of functional molecular mechanisms. Notably, they transfer RNAs and proteins between different cells that can then participate in the complex pathogenesis of allergic and related hypersensitivity responses and disease mechanisms, as described herein. This review highlights this important new appreciation of the in vivo participation of such extracellular vesicles in the interactions between allergy-mediating cells. We take into account paracrine epigenetic exchanges mediated by surrounding stromal cells and the endocrine receipt of exosomes from distant cells via the circulation. Exosomes are natural ancient nanoparticles of life. They are made by all cells and in some form by all species down to fungi and bacteria, and are present in all fluids. Besides a new focus on their role in the transmission of genetic regulation, exosome transfer of allergens was recently shown to induce allergic inflammation. Importantly, regulatory and tolerogenic exosomes can potently in-
\end{abstract}

hibit allergy and hypersensitivity responses, usually acting nonspecifically, but can also proceed in an antigen-specific manner due to the coating of the exosome surface with antibodies. Deep analysis of processes mediated by exosomes should result in the development of early diagnostic biomarkers, as well as allergen-specific, preventive and therapeutic strategies. These will likely significantly diminish the risks of current allergen-specific parenteral desensitization procedures, and of the use of systemic immunosuppressive drugs. Since extracellular vesicles are physiological, they can be fashioned for the specific delivery of therapeutic molecular instructions through easily tolerated, noninvasive routes, such as oral ingestion, nasal administration, and perhaps even inhalation.

(c) 2016 S. Karger AG, Basel

\section{Introduction}

Exosomes are exciting newly recognized extracellular vesicles that transfer a variety of bioactive compounds, including RNA molecules, proteins and lipids, between nearby cells in a paracrine manner, such as at synapses.

K.N. and K.B. contributed equally to this work.

\section{KARGER}

(c) 2016 S. Karger AG, Basel

E-Mail karger@karger.com

www.karger.com/iaa
Correspondence to: Prof. Philip W. Askenase

Section of Allergy and Clinical Immunology

Department of Internal Medicine, Yale University School of Medicine

333 Cedar Street, New Haven, CT 06510 (USA)

E-Mail philip.askenase@yale.edu 
This has been exquisitely shown at the central immunological synapse between T cells and antigen (Ag)-presenting cells (APC) [1]. Furthermore, locally secreted exosomes can then enter the vasculature to act systemically on distant cells in an endocrine manner. We have demonstrated this recently for splenic and lymph node-derived $\mathrm{T}$ suppressor (Ts) cell-secreted suppressive exosomes. They regulate the interface of APC and effector T cells at the peripheral tissue site of an immune inflammatory response [2]. Morphologically, exosomes are spherical vesicles with a bilamellar membrane that are 50-200 $\mathrm{nm}$ in diameter depending on the source and activation state of the donor cell [2]. They are formed by budding from the wall of terminal endosomes to then accumulate at the intracellular periphery in the multivesicular body (MVB). When the MVB undergoes exocytosis, there is the release of the contained bunches of exosomes into the extracellular space [3,4]. Alternatively, microvesicles bud individually from the cell surface, are larger (200-1,000 $\mathrm{nm}$ ) and mediate similar mechanisms with great overlap in the characteristics of exosomes. Together they are called extracellular vesicles. Study of exosomes is a new field concerned with very large numbers of very tiny vesicles, for which there are as yet no specially designed machines for their particular analysis. According to current experimental observations, there seems to be billions of exosomes per milliliter of blood, which is about a million times greater than the blood cells and they are one thousandth the size of the cells. Moreover, there is a great variability of vesicle types, with many subtypes in the exosome preparations [5]. There is also a significant variation in properties between individual exosomes, including their membrane content [6] and their contained proteome and types of RNAs [7-9], with yet further variability due to the stage of maturity and activation of the cells generating the exosomes $[2,10,11]$. The proteome and RNAome of exosomes differ markedly from those from their donor cells, indicating active mechanisms of their production, sorting and loading as cargo.

Exosomes are natural and physiological ancient nanoparticles of life, since they are made by all cells, are present in all body fluids and are made in some form by all species down to and through fungi [4] and bacteria [12, 13]. Accordingly, it is well known that bacteria produce microbial extracellular vesicles $(\mathrm{mEV})$ at their surface, formerly termed outer membrane vesicles, which enable the transfer of contents consisting of enzymes and toxins [14] to regulate other bacteria. Furthermore, mEV, also known as bacterial outer membrane vesicles (OMV), are now known to contain RNAs $[15,16]$. Importantly, mEV can crucially influence host allergic immune responses. They have the ability to drive clinical diseases, such as in atopic dermatitis, via the $\mathrm{mEV}$ from skin surface microorganisms commonly associated with this allergic disease, such as staphylococci [17] and fungi [18].

Compared to whole nucleated cells, exosomes offer cell-free therapy without the transfer of possibly oncogenic DNA. However, DNA fragments have recently been demonstrated in exosomes from cancer cells [19$21]$. Thus, in some instances the functions of cells can be replaced by their produced exosomes. A prominent example is that mesenchymal stem cell healing functions can often be completely replaced by their exosomes [2225 ], which in some cases has been shown to be due to identified exosome miRNA cargo [26, 27]. A very important difference from cells is that exosomes are resistant to harsh conditions, like a $\mathrm{pH}$ of $3-4[28,29]$ or even a $\mathrm{pH}$ of 1 [30], encountered in the gastrointestinal (GI) tract, as well as hyperosmolarity due to the expression of the water channel called aquaporin-1 [31], and hyperoxia [32] or hypoxia [33], when the exosome donor cells are stimulated under those conditions. Therefore, extracellular vesicles, such as exosomes from various sources, play a newly recognized, important and diverse role in physiological processes and pathological conditions relevant to diseases, such as those of allergy and hypersensitivities.

\section{Exosome Transfer of Signaling Proteins and Genetically Active RNAs Pertinent to Allergy and Hypersensitivity}

There is a well-recognized role of exosomes in allergy [34]. The outstanding new property that exosomes bring to allergic and other responses is the transfer between cells of functional genetic material and signaling proteins. Transferred regulatory RNAs can then epigenetically alter gene function in the acceptor cells [35-41], while transferred signaling proteins, like wnt, can alter their intracellular functions [42-45]. Accordingly, such transfer of genetic information has been shown for immune [4650], hypersensitivity [2], IgE [51] and allergic asthmatic [52] responses. Such intercellular communication and consequent regulation at the genetic level is unprecedented in human physiology and disease processes. Therefore, this greatly widens the possibilities of a more complete understanding and more precise interventions in allergy and related immune-mediated diseases. As noted, there is a great variability between exosomes, even those produced by the same cell [6], in their proteome [53] and 
RNAome. Importantly, functional mRNA and miRNAs can be a small percentage of the total exosome RNA [2, $54,55]$. However, functions of many of the miRNAs still have to be delineated. The remaining RNA cargo is usually made up of other classes of RNA, including long noncoding RNAs of unknown significance, along with numerous ribosomal RNA fragments and tRNAs, also of unknown functions $[2,54,55]$. Therefore, the exosome exchange of molecules between cells is a sophisticated and potentially quite heterogeneous process of great complexity. This has diverse functional consequences for the mediation and modulation of cellular functions in immunity, allergy and hypersensitivity. On a wider level, the potential for exosome transfer of functional RNAs and signaling proteins from neighboring and distant cells of other systems that previously were mostly thought to be independent of allergy and immunity. However, these microenvironmental tissue cells now should be seen as likely to be interacting with or affecting the cells mediating allergic and immunological responses. For instance, exosomes derived from various cell types of the microenvironment influence the established immune cell-cell interactions in allergy and immunity, and thus are now considered as important in actual in vivo circumstances. Figure 1 shows how this might apply to interactions of the various immune and stromal tissue cell populations in the airways of asthma patients. The intercellular transfer of RNAs mediating epigenetic changes and exchange of signaling molecules, including transcription factors [56], or their regulators [57], makes this a powerful new source for a fuller understanding of allergy and hypersensitivity. Consequently, this should provide new diagnostic opportunities and therapeutic maneuvers to potentially intervene in allergic and immunological disease processes at entirely new levels.

\section{Effects of Exosome Intercellular Interactions on Allergy and Immunity}

According to the above considerations, exosomes have recently been shown to exhibit great effects on immunological activities as mediators involved in many stages of immune and inflammatory responses, such as induction, orchestration, elicitation, resolution and regulation. As an important example, T regulatory (Treg) Foxp $3^{+}$cells produce exosomes that suppress Th1 cell proliferation and cytokine production via gene silencing due to transferred Treg cell-derived miRNAs [58]. Furthermore, thymic epithelial cells produce exosomes carrying tissue-re-

Exosomes in Allergy and Hypersensitivity stricted Ag that guide the development of the Treg cells $[59,60]$.

Signaling pathways can also be altered by either exosome-transferred miRNA influencing translation by mRNA inhibition in the targeted cell, the transfer of mRNA to alter the production of specific proteins in the targeted cells, or exosome transfer of the proteins themselves. For instance, the signaling molecule wnt can be gained $[44,45]$ or lost by cells via exosomes [42]. Further, this protein can be expressed on the exosome surface and, thus, may potentially be transferred between cells in such a form [43]. Importantly, inflammation and immunity can also be influenced by the transfer of exosome-containing cytokines [61-64], their receptors [65], and signaling molecules [65], by stimulation of cytokine production via exosome-derived TLR agonists [61], or finally by cells activated by exosomes. This includes $\mathrm{T}$ cell vesicles activating mast cells $[66,67]$ as well as the exosome transfer of mRNA encoding mast cell cytokines [38].

Furthermore, endogenously induced, natural exosomes, or those modified ex vivo, can carry and transfer immunoregulation via miRNAs that might be altered for application in the therapy of diverse allergic diseases and for better control of dysregulated immune responses, as well as for influencing hypersensitivity mechanisms that underlie clinical disease processes. With the growing prevalence of allergies, hypersensitivities and diseases with immune-mediated manifestations, this newly recognized function mediated by previously unknown exosome intercellular transfer of epigenetic regulation joins the currently unraveled genetic and molecular mechanisms underlying their complex pathogenesis. Many other aspects of these disorders remain to be clarified by further and deeper investigation and then translation into clinical understanding and new therapies. These also seem to depend on the exosome transfer of gene regulation and cell signaling. This current review particularly highlights the involvement of these processes in allergic and immunological diseases that have recently shown increasing prevalence and severity. A revealing example relevant to allergy concerns $\mathrm{CD} 23^{+}\left(\mathrm{Fc \varepsilon R}-2^{+}\right) \mathrm{B}$ cells that capture immune complexes consisting of IgE and allergen as Ag to then produce exosomes (B cell exosomes called 'bexosomes') carrying CD23, IgE and MHC class II, which are transferred to dendritic cells (DC) that in turn stimulate Ag-specific T cells [51]. This suggests that 'bexosomes' can provide the essential transfer mechanism for IgE-Ag complexes from B cells to DC for the subsequent activation of allergen-specific $\mathrm{T}$ cells. In this case, anti-IgE or rituximab (anti-CD20) therapy should block this process. 


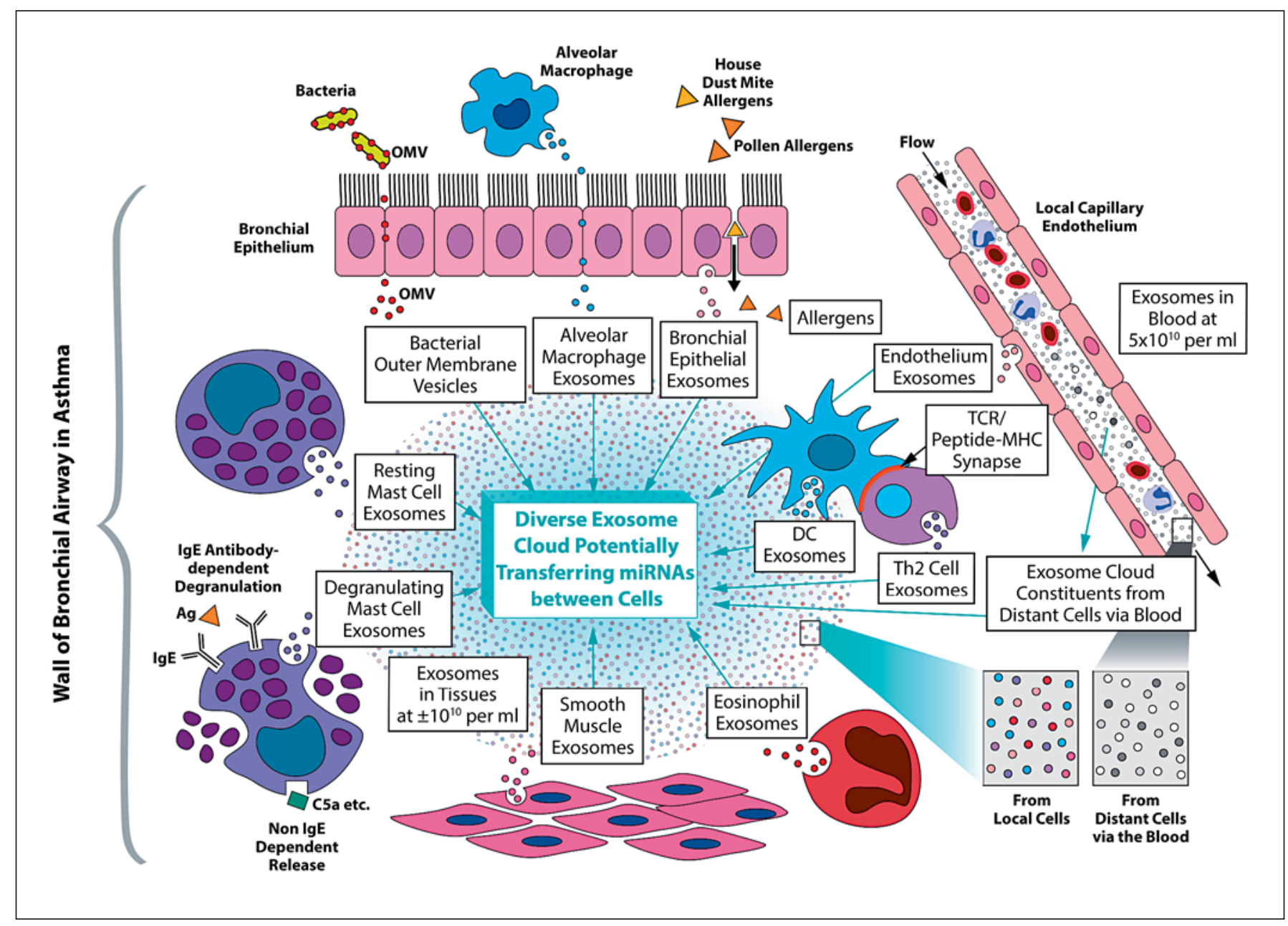

Fig. 1. Proposed details of a postulated exosome cloud in the airways of asthmatic patients and other relevant tissues like the nasal mucosa. The tissue cloud consists of diverse exosomes derived from various cell sources that have a variety of cargos. The exosomes and other related extracellular vesicles in this cloud are postulated to be at a concentration of about $10^{10}$ vesicles per milliliter in the interstitial fluids between the various cells, shown as tiny spheres of different colors expanded in the lower right. The extracellular vesicles from donor cells are able to transfer miRNAs, other RNAs and proteins, etc., to other cells via the fluid between them to potentially alter the functions of the acceptor cells epigenetically. This diverse intercellular transfer of genetic information can be mediated by exosome-derived miRNAs and is potentially able to alter the development, maturation, activation and importantly function of other cells of various types. Some of these exosomes of the local cloud likely leave this tissue site to enter another cloud in the draining lymph to affect distant cells, such as those in the bone marrow or the cells of other organs like immune cells in the spleen or lymph nodes, via entering another cloud in the systemic circulation. Those in the blood are a mixture from all or most of the cells in the body to potentially serve as accessible clinical markers of disease. The circulating exosomes head for all possible sites, including those from elsewhere to the bronchial airway in asthma, shown in the figure to the right, along with exosomes from the endothelium (expanded in the lower right) to enter this site to join the local cloud to potentially exert effects on its constituent cells, thus in an endocrine manner. Note that the local cellular interactions not only involve the usual cross talk between lymphoid $\mathrm{T}$ and B cells and Ag-presenting DC (some in immunological synapse, mid central right of the figure) and macrophages, with other myeloid-derived cells like eosinophils and mast cells. Very importantly, these immune and myeloid cells interact via mutually released exosomes with other local cells of the microenvironment, like bronchial epithelium, smooth muscle cells, as well as fibroblasts and other cells of the stroma that lie between all of the above cells. Furthermore, note that constituent cells send out exosomes at baseline for physiological interactions and then other 'activated' exosomes when the cells are stimulated like the mast cells (to the left) responding to inhaled allergen (top right) or C5a, or cells responding to $\mathrm{mEV}$ from bacteria in the airways (top left). These newly recognized intercellular genetic interactions mediated by diverse exosomes in an intercellular cloud are present in addition to the already known exchanges based on conventional cytokines and their receptors, along with 'micromediators', like histamine, leukotrienes and C5a. 
Other examples of exosome-mediated intercellular influences in immunity, hypersensitivity and allergy, include: (1) helper $\mathrm{T}$ cell augmentation of $\mathrm{B}$ cell production of $\mathrm{HLA}^{+}$exosomes [11], (2) T suppressor [2] and Treg [58] cell-derived exosome inhibition of effector Th1 cells, (3) thymic epithelial cell-derived Ag carrying exosomemediated maturation of Treg cells [59, 60], (4) DC activation of other DC and also B cells [50], (5) T cell activation of APC and DC [49], and (6) the opposite, i.e. DC-derived exosomes stimulating $\mathrm{CD}^{+} \mathrm{T}$ cells [68]. Furthermore, DC can be guided by exosomes with MHC class II and costimulatory molecules present in human bronchoalveolar lavage fluid (BALF) [69], and by mast cell-derived exosomes inducing phenotypic and functional maturation of DC to elicit specific immune responses in vivo [70].

Exosome-mediated intercellular interactions involving mast cells are particularly relevant to allergy. These include: $\mathrm{T}$ cell exosome activation of mast cells $[66,67]$, and mast cell activation of $\mathrm{T}$ and $\mathrm{B}$ cells $[71,72]$, mast cell exosome-mediated phenotypic and functional maturation of DC [61, 62] and endothelial cells [73], or other mast cells or progenitor stem cells [74]. These effects can be induced via exosome-transmitted cytokines $[66,75]$ or mast cell exosome transfer of mRNA encoding the cytokines [37], and by affecting cytokine signaling [75] or triggering cytokine production by bronchial cells [76] or by airway smooth muscle cells [77]. Finally, mast cell exosomes induce phenotypic and functional maturation of DC enabling them to elicit specific immune responses in vivo [78], they activate endothelial cells to secrete clotting factors [73] and can activate T and B cells $[79,80]$.

Taken together, such intercellular exchanges via exosomes occur in established processes dominant in classical allergic mechanisms, for instance in the release of traditional mast cell mediators, like histamine, bioactive peptides, leukotrienes and even cytokines. These traditional proallergic mediators affect surrounding cells in classical type I immediate hypersensitivity. Additionally, target cells are likely modified by miRNAs and other elements transferred by the mast cell-derived exosomes to mediate epigenetic changes in these cells. Furthermore, the releasing mast cells themselves are now seen as being affected by exosomes from surrounding and even distant cells (fig. 1).

Of additional relevance to mechanisms of allergic asthma, these patients have increased numbers of airway exosomes expressing $\mathrm{MHC}$ and costimulatory molecules that may play a similar role as APC $[69,81]$. Furthermore, among the increased numbers of exosomes in the airways of mice with a model of asthma, the bronchial epithelial cell-derived exosomes stimulated by IL-13 induce the activation of macrophages [77], and exosomes play a role in the Th2 activation of local auxiliary cells $[77,78]$, acting via specific cell surface cytokine receptors, such as IL-4 receptor. This seems to influence the triggering of established intracellular signaling pathways that regulate gene expression of Th2 responses. Eosinophil-derived exosomes are also suspected to play a role in asthma pathogenesis [78]. Thus, it now must be considered that established allergic mast cell activation for mediator release, as well as conventional intercellular cytokine-dominated pathways, are proceeding in parallel with, or more likely interact with the donation and receipt of a variety of intracellular communications arising locally or from distant cells via the blood. Simultaneously they are triggered by epigenetic effects of exosome-derived miRNAs and mRNAs, or proteins transferred between these cells (fig. 1). These newly recognized exosome influences described as an intercellular cloud of diverse exosomes from immune, inflammatory and tissue cells result in modulation of the established mechanisms of allergic and hypersensitivity responses and, thus, likely play an important role in allergic and immunological diseases.

\section{Mast Cell Exosomes Act in Allergen Ag Presentation}

It was previously shown that classical APC, like macrophages and particularly DC, pulsed with whole native Ag release immunogenic exosomes that have surface complexes of the Ag-peptides in MHC molecules. These exosomes can act as 'mini-APC-like' substitutes, which can bind to T cell surface Ag-MHC-specific TCR receptors to induce $\mathrm{T}$ cell signaling for effector functions [7981], such as activation of $\mathrm{CD}^{+} \mathrm{T}$ cells [68]. As above, sensitization for allergic atopic type I responses involves allergen engulfment and then intracellular processing by APC, principally DC, but also macrophages. The subsequent cell surface Ag presentation of DC-digested Ag peptides derived from allergen proteins, to the effector Th2 lymphocytes stimulate their release of helper cytokines, like IL-4 and IL-13. These act on IgE-positive B cells that produce allergen-specific IgE $\mathrm{Ab}$ and on asthma-associated tissue cells, like goblet cells, to produce eosinophil-recruiting chemokines.

New findings pertinent to this review show that besides DC and macrophages, mast cells can function similarly as APC in Th2 responses, also by taking up allergens to possibly generate similar Ag-presenting exosomes. 
However, it remains possible that these are taken up by DC or B cells [82] to then truly present Ag [83]. Such transfer of mini-APC may thus account for transferred functions at a mast cell and DC synapses $[1,84-86]$. They are connected with the demonstrated ability of mast cell exosomes to induce the maturation of DC that allows for their conventional Ag presentation to $\mathrm{T}$ cells [70]. IgE antibodies $(\mathrm{Ab})$ may also play a role in this mast cell exosome in Ag presentation. Thus, mast cell-released exosomes express FceRI receptors that may be involved in the reuptake of $\operatorname{IgE}$ complexed with allergen, not only by mast cells but in humans also by conventional APC also expressing FceRI. This in turn likely mediates allergen presentation [87].

At such newly described mast cell synapses formed with other cells, like that recently shown at the central immunological synapse of T cells and APC or B cells [1], there is intercellular passage of RNAs and proteins from the released mast cell exosomes. Thus, during the effector phase of allergic responses, apart from classical allergenspecific IgE-mediated degranulation of mast cells to release diverse proallergy and inflammatory mediators. However, there also is an additional layer of molecular mediator release due to exocytosis of MVB-derived exosomes that may transfer regulatory RNAs and proteins to neighboring cells $[70,71]$. Note that the first description of exosome-mediated intercellular exchange of functional RNA was shown in mast cell lines. Here, the appearance of donor cell proteins in the acceptor cells due to the transferred mRNA, and interestingly some of the mRNAs were hardly expressed in the donor cells [38].

The release of Ag/MHC-coated exosomes by traditional APC and mast cells represents an entirely new aspect of Ag presentation. Not only does the process proceed at the immunological synapses between APC and effector T cells [1], but likely also during the interaction of APC exosomes with $\mathrm{T}$ cells, which can be envisioned as a cloud of 'miniAg-presenting' exosomes around T cells (fig. 1). This would greatly change the stoichiometry of the APC phenomenon, since the existence of such an Ag-presenting exosome cloud would greatly enlarge this essential and central immune cell interaction. This therefore will not merely depend on the membrane to membrane colocalization of the T cell and APC for the formation of the conventional synapse between the surfaces of rare DC acting as APC, with passing rare Ag-specific T cells. In an analogous fashion, it seems that there is also a potential cloud of effector $\mathrm{T}$ cell-derived exosomes expressing membrane TCR and CD3 that are capable of binding with Ag/MHC complexes on the cell membranes of neighboring Ag-pre- senting B cells to trigger their function [1]. Also, and conversely, a mini $\alpha \beta T C R / C D 3 \mathrm{~T}$ cell exosome cloud backstimulating the B cell or DC. Thus, a molecular exosome RNA-mediated epigenetic effect of the T cells on the APC $[36,37]$ or similarly on B cells [1], and, conversely, of the APC on the T cells [60], and even stimulated DC activating other DC, are newly recognized aspects of central immunological processes. This opens possible new levels for understanding and treating allergic and hypersensitivity diseases. Therefore, this novel exosomal Ag presentation process can be exploited for new modes of allergen desensitization, which could perhaps be reduced from the use of native allergens to just treating patients with APC-derived exosomes, as is currently done for vaccination against infectious agents [88,89] and cancer [90-92].

\section{Exosome Involvement in Allergic Rhinitis and Possibly in Nonallergic Rhinitis}

Intriguingly, there is a relevant study that extends the concepts described above about APC exosome allergen presentation. Cultured B cells from patients allergic to birch pollen, including those with allergic rhinitis, who have $B$ cells expressing surface Ig receptors (BCR) of the same allergen specificity as their produced $A b$, released Ag-specific exosomes with BCR on their surface. After in vitro loading with a birch pollen-derived allergenic peptide Bet v 1, these anti-birch pollen-specific B cell exosomes were used as mini-APC to stimulate patient T cells. This new exosome mediated $\mathrm{B}$ and $\mathrm{T}$ cell collaboration caused in vitro $\mathrm{T}$ cell proliferation and secretion of the Th2-dependent cytokines IL-5 and IL-13, which likely could participate in the allergic rhinitis and asthma [93].

It was shown recently that there is great diversity of miRNA expression in tissues of nasal mucosal biopsies from patients with persistent and also nonpersistent asthma in comparison to healthy volunteers [94]. In another relevant study, analysis of the miRNA profile in extracellular vesicles obtained from the nasal mucus of patients with allergic rhinitis revealed differences when compared to healthy individuals. This implies that nanovesicletransmitted RNAs may likely also be involved in the pathogenesis of this most common type I allergic disease [95]. Also, there is an association of mRNA levels in nasal polyps with the release of eosinophil mediators, like RANTES and eotaxin [96]. This raises the possibility of treating nasal polyps with intranasally administered exosomes containing RNA antagonist of the reverse sequence to the polyp-associated mRNAs or miRNAs. Finally, the isola- 
tion of nasal mucosal and epithelial samples from patients with chronic obstruction due to atypical allergic rhinitis for their further examination using immune gold electron microscopy showed that the resulting exosomes carried relevant nasal allergens, like staphylococcal enterotoxin B and house dust mite-derived Der $\mathrm{p} 1 \mathrm{Ag}$. These exosome mini-allergen-APC were claimed to induce naive $\mathrm{CD}^{+} \mathrm{T}$ cells to differentiate into $\mathrm{CD} 8^{+} \mathrm{T}$ cells. Furthermore, on exposure to specific $\mathrm{Ag}$, the $\mathrm{CD} 8^{+} \mathrm{T}$ cells released granzyme $\mathrm{B}$ and perforin, and more than $30 \%$ of the Ag-specific $\mathrm{CD}^{+} \mathrm{T}$ cells proliferated [97]. An interpretation of these data suggests that this could be an example of functioning in vivo allergen-positive APC-derived exosomes that are able to stimulate $\mathrm{T}$ cells in the pathogenesis of chronic atypical rhinitis. Exosomes collected from human nasal lavage fluid were shown to induce the migration of innate immune cells that may play an important role in the defense against pathogens and allergens. On the other hand, the decreased expression of antimicrobial proteins in nasal exosomes from patients with airway diseases likely contributes to an increased susceptibility to infections and to disease progression [98].

Thus, it could be postulated that similar clinical syndromes seeming to be independent of IgE Ab might be caused by pathogenic exosomes from local and/or distant cells that perhaps act in an Ag-specific manner. Alternatively, the mechanism underlying these clinical symptoms could be due to a combined action of such mini-APC exosomes and very low levels of IgE Ag-specific Ab that do not cause the elicitation of macroscopically positive skin tests or other in vitro tests. This recalls our demonstration in mice that very low amounts of IgE ( $1 \mathrm{ng}$ per mouse equal to 2 pg per person) failed to elicit macroscopic immediate skin responses to allergen challenge. However, they still mediated microscopic type I vasoactive responses that in fact can allow for the local recruitment of hypersensitivity effector T cells into the tissues [99].

Another hypothesis involves cross-kingdom considerations pertinent to exosomes, such as the action of foodderived miRNAs carried from the intestine by host exosomes to influence a human patient with allergy [100]. In this regard, it is postulated that extracellular vesicle-delivered enzymes or RNAs produced by the allergy-inducing plants, or even released from their pollens [101], or in allergy to house mites, since insects are known to release exosomes from their MVB $[44,45]$, may play a role in some of these atypical clinical conditions [102]. Accordingly, exosomes derived from DC of patients exposed to cats, carrying the major peptide determinant of cat allergen (Fel d 1), were recently shown to potently stimulate

Exosomes in Allergy and Hypersensitivity cytokine production by Th2 lymphocytes in cat allergen sensitive individuals [103]. On the contrary, particular miRNAs from exosomes of nasal epithelial cells from this atypical allergic rhinitis microenvironment stimulate IL10 production by monocytes to inhibit nasal allergy [104]. Thus, this sort of allergen-induced exosome mediated intercellular communication might be responsible for the seemingly anomalous finding that, although cat dander is very sensitizing and produces strong symptoms in many atopic individuals, exposure to multiple cats curtails this powerful allergic sensitivity. This could be due to participation of exosomes in a 'modified Th2 response'. This is characterized by an emerging role of Ag-specific Treg cells and associated IgG4 Ab responses that prevent the specific allergic reaction in allergic individuals, and of clinical practice interest may constitute the results of clinical desensitization with high doses of cat allergen [105], as is true of desensitization with stinging insects [106], and also experimental high antigen dose tolerance due to suppressor T cell eosomes [2, 7].

Additionally, tissue iNKT cells may be involved in such exosome communications, since exosomes express not only MHC but can also express the minor histocompatibility CD1d molecules known to bind glycolipid Ag, like alpha-galactosylceramide ( $\alpha$-gal-cer) the canonical glycolipid Ag activating semi-invariant $\alpha \beta$ TCR on iNKT cells [107]. Such mini-APC exosomes with surface CD1d may stimulate tissue iNKT cells to release allergy-promoting Th2 cytokines, like IL-4 and IL-13, after interaction with host, plant or mite glycolipids. As a result, these CD1d-dependent iNKT cells may induce allergic responses against glycolipid Ag with the release of IL-4, as we showed previously in contact hypersensitivity [108], or IL-13 reacting against polysaccharides from bacteria, as we showed in a murine model of pneumococcal pneumonia [109], or the plant pollens [101], as a requirement for eventual effector Th1 cell participation.

Very interestingly, plant allergens that play a major role in atopic allergic rhinitis and asthma have been known for a long time to be associated with their pollens, and recently were shown to be released from pollens in exosome-like vesicles called 'pollensomes' [110]. Regarding such interactions in food allergy, extracellular MHC class II-positive exosomes released by epithelial cells of the GI tract, which have mini-APC abilities, may play an important role in the transmission of sensitizing food allergens from the intestinal lumen to the local lymphatic system [111]. This intercellular exosome communication may thus allow for Ag-presentation by DC to specific T cells. Such a T cell response to the dietary Ag of these mini-APC exosomes 
may initiate and then aggravate the responses to food allergens. Distinctly, these conditions may be represented by patients with food allergy induced by iNKT cells reacting to the APC-derived exosomes pulsed with the plant $\mathrm{Ag}$, and, therefore, producing clinically significant symptoms, but lacking the IgE mediated positive result of immediate skin tests to the food allergens, a frequent finding. Moreover, exosomes were recently shown to transfer haptenated proteins to possibly activate allergy to $\beta$-lactams in a model of clinical allergy to amoxicillin [112]. Host cell-derived exosomes and cross-kingdom allergens presented on mini-APC exosomes should now be considered to possibly be involved in several other atopic disease imitators that apparently are not due to classical IgE/mast cell mechanisms.

\section{Bacterial Microbial Extracellular Vesicles (mEV) Promote Atopic Dermatitis}

Remarkably, allergens can also be transmitted by extracellular vesicles originating from microbiome that can significantly drive clinical allergic diseases. As an example, Staphylococcus aureus is known to be strongly associated with the pathogenesis and progression of atopic dermatitis. Accordingly, antistaphylococcal antibiotic therapy and/or daily immersion in Clorox mixed in a bath are routinely prescribed for patients with this disease. It has been known for a number of years that bacteria secrete $\mathrm{mEV}$, which now are seen as related to exosomes. $\mathrm{mEV}$ are formed at the cell surface from budding off of a very thin tissue cell layer over the tough peptidoglycan outer calix that surrounds the bacterial cell membrane for maintaining shape and protecting against challenging environments and enemies.

The $\mathrm{mEV}$ are subsequently extruded as vesicles containing signaling molecules for quorum sensing by other bacteria, leading to promotion of microbial growth and spreading. They also contain enzymes and toxins for fighting enemies, and importantly RNAs, as recently demonstrated $[15,16]$. These extracellular vesicles enable the bacteria to mediate long-distance delivery of toxic cargo with minimized dilution or degradation in transit to then optimally affect other organisms. Of clinical interest, these properties allow for the transmission of bacterial factors mediating invasion and virulence to act at the host-pathogen interface, and to participate in some allergic diseases, like atopic dermatitis $[17,18]$. Accordingly, application of $\mathrm{mEV}$ from $S$. aureus to mouse skin, previously stimulated by local tape stripping and then Ag application to express a murine model of atopic dermatitis, results in the augmented development of the characteristic eosinophil-rich inflamed lesions along with the increased local levels of Th2 cytokines [17]. Furthermore, these staphylococcal $\mathrm{mEV}$ are able to stimulate dermal fibroblasts to release stromal-derived proallergic inflammatory mediators, like TSLP, IL-6, MIP-1a and eotaxin to possibly initiate or aid progression of atopic dermatitis, and also to induce $\operatorname{IgE}$ responses to microbial Ag, particularly found in the $\mathrm{mEV}$, compared to the whole staphylococci [17].

In a related study, a large group of patients with atopic dermatitis was found to be reactive to Malassezia sympodialis fungal allergens that were shown to be carried by $\mathrm{mEV}$ released by this yeast [18]. Like staphylococci, this yeast is considered a part of the physiological cutaneous flora. These allergen-bearing fungal exosome-like mEV isolated from the supernatant of the coculture of $M$. sympodialis and monocyte-derived DC collected from patients with atopic dermatitis are able to stimulate the in vitro production of IL- 4 by cultured peripheral blood mononuclear cells from these patients [18]. In an analogous manner, the $\mathrm{mEV}$ of the nasal microbiome may participate in allergic rhinitis to promote this most common type I allergic disease. Accordingly, molecular evidence based on bacterial 16s-ribosomal sequencing shows a possible relationship between the bacterial type and clinical outcome, and the dominance of $S$. aureus is being associated with the development of chronic rhinosinusitis [113]. Taken together, these data suggest that infectious agent-derived $\mathrm{mEV}$ transport microbial allergens and likely deliver functional RNA and proteins that are involved in the pathogenesis of atopic allergic diseases.

\section{Helminthic Worm Exosome miRNAs Inhibit Host Th2 Immunity to Mediate Molecular Parasitism}

Related to the role of exosomes in allergy is recent work showing that the mucus oily surface secretion of an intestinal helminth, called 'worm spit', known to be associated with its pathogenicity, contains exosomes with proparasitic and antiallergic miRNAs [114-116]. It is known that such worm-derived exosomes are taken up and internalized by cells of the parasitized host [115]. The recently uncovered mechanism of the molecular pathogenic role of these Darwinian evolved and naturally selected parasite miRNAs is to specifically bind to the $3^{\prime}$ untranslated region of targeted specific mRNAs in the host, to antagonize them or cause their degradation. They thereby alter gene translation epigenetically to then affect 
host immune cell function by decreasing the production of the targeted gene-encoded proteins [114]. This provides a newly recognized exosome-mediated molecular mechanism of parasitism; acting in this case by inhibiting translation of Th2-associated genes, like those encoding IL-33, which is an IL-1-related cytokine that normally enhances Th2 immune responses. This contributes to the downregulation of innate type II immune responses that are known to be associated with repelling worm infestation, and simultaneously promoting anti-worm Th2 responses [114]. Therefore, it has been proposed that extracellular vesicles of helminth origin, which are internalized by host immune cells, transfer inhibitory miRNAs for genetic downregulation of Th2-associated host-protective proteins. Clinically, the possible eventual use of these particular miRNAs, perhaps delivered in therapeutic exosomes, could be applied to treat type I allergies in patients, employing natural and physiological mechanisms.

Other related work also demonstrates the role of exosomes in the evolution of parasitism. It was shown that Leishmania constitutively secrete exosomes in the gut of the sand fly vector to become a part of the parasite inoculum transferred by the fly into the host during the insect's bite [117]. The cotransferred exosomes influence the infectious process by inducing host inflammation, particularly via IL-17a. The Leishmania-derived host exosomes are an integral part of the parasite's infectious life cycle, acting as newly recognized virulence factor vesicles that are associated with this vector-transmitted infection [118]. Prior work has demonstrated that Leishmania parasitism is augmented by the production of exosomes modulating host innate and adaptive immune responses through their effects on monocytes and DC [118]. Conversely to helminth exosomes that block host Th2 responses, vesicles shed by Trypanosoma cruzi parasites increase parasitism in the heart and generate an intense inflammatory response due to their induction of Th2 cell production of IL-4 and IL-10 [119]. Finally, it was shown that Trichomonas vaginalis-derived exosomes also deliver factors to the host that favor their infectivity [120].

\section{Role of Exosomes and Contained miRNAs in Interactions between Airway Tissue Cells and Infiltrating Asthma Pathogenic Immune and Inflammatory Cells}

As noted above, asthma can be augmented due to allergen-presenting exosomes. The disease can progress in sensitized individuals due to chronic airway exposure to inhaled aerosol allergens. This consists of either limited seasonal contact with allergens of outdoor plants or yearround contact with indoor allergens from house dust mites and the dander of mice and pets. Beyond the acute clinical bronchospastic phase, asthma is associated with 'late-phase', eosinophil-rich airway inflammation. These chronic manifestations can lead to airway tissue remodeling with fibrosis and airway muscle sensitization that induces easily provoked bronchoconstriction, with all significantly impairing the life and comfort of patients.

These phases of asthma are classically noted to be mediated by IgE-dependent, early immediate hypereactivity, and subsequent late-phase inflammation resulting from IgE and Th2 cell-dependent mechanisms. This latter process, which is critical to the generation of chronic asthma, includes crucial interactions between local tissue cells of the airway microenvironment and the infiltrating immune inflammatory constituents. These interactions are now recognized to be mediated, at least in part, by released extracellular vesicles that transfer their miRNA and protein content between the involved cells (fig. 1). This likely includes exosomes exchanging information between the intrinsic lung tissue cells of the local airway microenvironment, and extracellular vesicles derived from infiltrating immune and inflammatory cells emigrating to the lungs from the bone marrow and lymphoid tissues. The local microenvironmental exosome sources include cells of airway smooth muscles, vasculature, and epithelium, as well as mast cells, goblet cells, DC, and alveolar macrophages.

We postulate that these wider than previously anticipated interactions produced by exosome-mediated intercellular exchanges between cells of the tissue microenvironment and the infiltrating immune and inflammatory cells are important in the development of chronic airway remodeling. This is analogous to the newly expanded ideas of tissue stromal cell responses to cancer cells spreading metastasis $[121,122]$. Interestingly, this can depend on chronic exposure to tumor cell-derived exosomes delivering proteins or RNAs that act on the tissue cells. It was demonstrated that exosomes from particular cancers act at a distance to fuse specifically with resident cells of the preferred organ to generate a premetastatic niche. This appears to be due to specific, Darwinian selected exosome surface integrins. These could be considered as analogous to bar codes for specific recognition affinity of other particular cells [123]. By analogy, cells within an allergic tissue, such as in the late or especially remodeling phase of asthmatic airway inflammation, could generate a bronchial microenvironmental multi- 
cellular-derived cloud of exosomes with specific affinities for various local, or distant, targets driving the allergic tissue response (fig. 1). Thus, the local airway tissue cells are often the targets of immune and inflammatory cellderived cytokines inducing the production of chemokines and enzymes, like in chronic obstructive pulmonary disease [124], and, furthermore, can often be the targets of exosomes [81, 125, 126].

\section{BALF Analysis Suggests the Participation of Exosome Intercellular Exchanges in the Pathogenesis of Allergic Asthma}

Exosomes derived from the BALF of healthy individuals differed from those of patients with even mild asthma that expressed higher levels of exosome-associated markers, such as the tetraspanins CD63 and CD81, and the scavenger receptor CD36 [127]. Although there were no major differences between BALF exosomes from asthmatics before and after birch pollen allergen provocation, they contained enzymes for leukotriene biosynthesis that were able to promote $\mathrm{LTC}_{4}$ release, as well as the synthesis and release of the neutrophil-recruiting IL-8. Importantly, a leukotriene receptor antagonist (montelukast) reduced exosome-induced secretion of this proinflammatory cytokine that behaves like a neutrophil chemokine [127].

Furthermore, in a mouse model of asthma, exosomes isolated from the BALF of asthmatic versus control mice had increased levels of exosome-associated proteins. The asthma featured enhanced secretion of exosomes by bronchial epithelial cells, but not macrophages. Stimulation of the epithelial cells with IL-13 to imitate the function of specific allergen-pulsed Th2 cells, which is common in asthma, enhanced asthma severity [76]. This resulted in the release of exosomes from the bronchial epithelial cells that induced the proliferation and chemotaxis of macrophages. These effects were suppressed by treatment with the ceramide blocker GW4869 [76], an inhibitor of neutral sphingomyelinase- 2 that is essential for exosome formation. Thus, it is known to inhibit exosome transfer [128-130] and, indeed, it alleviated allergic airway inflammation in these asthmatic mice [76]. Interestingly, isolated wild-type mast cells stimulated with $\mathrm{Ag}$ for typical mediator release were strongly inhibited in sphingomyelinase-deficient mice [131]. However, a possible role of an activating exosome exchange between mast cell subtypes for mediator release has not been investigated yet.
Pertinent to possible exosome-derived miRNA regulation of asthma are experiments showing that allergic disease resulting from in vivo activation of TLR4 by house dust mite Ag leads to expression of a unique subset of miRNAs. Remarkably, selective blockade of miRNA-126 alone with specific antagonists inhibited the asthmatic phenotype. This resulted in diminished Th2 inflammation, airway hyperresponsiveness, eosinophil recruitment, and mucus hypersecretion [132]. The data suggest that targeting miRNA in the airways, possibly in exosomes, may lead to anti-inflammatory treatments for allergic asthma. In a follow-up study using the ovalbumin (OVA)-induced asthma model, specific inhibition of prominently involved miRNA-155 with antagomir treatment failed to alter the disease phenotype, leading to the conclusion that the level of a particular miRNA may not indicate its importance and that blocking is needed to ascertain the functional significance of a particular miRNA from exosomes [133]. Interestingly, there was the variable efficacy of the anti-miRNA treatment across different immune cell types. Thus, effective targeting of myeloid cells but not lymphocytes indicated the possible need for cell type-specific targeting of such therapy. Taken together, these data show that exosomes produced by various cells in the airways have an important and previously unrecognized role in the pathogenesis of the acute early phase of atopic allergic asthma. Since exosome effects are often mediated by the intercellular transfer of miRNAs, these findings raise the possibility of new therapies at an entirely new level; namely blocking the epigenetic effects of miRNAs with appropriate polynucleotide antagonists, as we demonstrated in the inhibition of effector T cell mediated cutaneous contact hypersensitivity (CHS) mediated by delivery of miRNA-150 in suppressive exosomes $[2,7]$.

\section{Potential Role of Exosomes in Airway Remodeling during the Late Phase of Asthma Inflammation}

Exosomes produced by eosinophils may possibly contribute to tissue remodeling during the late phase of asthma [78, 96, 134-136]. Eosinophils collected from the blood of asthmatic patients that were stimulated in vitro with cytokines had increased release of tetraspanin $\mathrm{CD}^{+} 3^{+}$ exosomes [136]. Potential augmenting of the number of eosinophil-derived exosomes can alter and even cause rapid necrosis of structural lung cells that can not only exacerbate allergic asthma, but can especially lead to airway remodeling [133]. These effects may be greater than
Nazimek/Bryniarski/Askenase 
expected, since it is possible that some of the granules thought to be produced by eosinophils may in fact be exosomes.

In an analogous manner bronchial epithelial cells seem to produce proinflammatory exosomes that activate macrophages in the inflammatory phase via the transfer of miRNA. Th2 cell-derived IL-13 stimulates airway epithelial cells to release exosomes that transfer Let-7 miRNA to activate macrophages in the lungs during asthmatic inflammation [137]. During the inflammation neutrophils may also contribute to subsequent remodeling. Here, the $\mathrm{LTB}_{4}$ induces neutrophil chemotaxis; their released exosomes contain $\mathrm{LTB}_{4}$ and its synthesizing enzymes [138], and can activate neighboring resting neutrophils in an $\mathrm{LTB}_{4}$ receptor-dependent manner [139]. Thus, the exosomal pool of $\mathrm{LTB}_{4}$ acts in an autocrine fashion to sensitize neutrophils towards a primary chemoattractant, and then in a paracrine fashion to mediate the recruitment of neighboring neutrophils to augment inflammation. Therefore, this forms an exosome intercellular mediator cascade effect, augmenting inflammation pertinent to the late phase of asthma and perhaps contributing to the progress of remodeling [140]. Accordingly, the use of drugs to inhibit exosome production might interfere with this deleterious augmenting cascade. Furthermore, airway administration of lipopolysaccharide (LPS) causes acute injury with the recruitment of neutrophils into the lungs and BALF [141]. Finally, neutrophils stimulated with LPS produce exosomes that alter the proliferative properties of airway smooth muscle cells [126]. In an analogous manner, LPS activates the bronchial epithelial cells of asthmatic patients to release exosomes that contain overexpressed proangiogenic tissue factor stimulated by compressive stress, which possibly also contributes to airway remodeling during chronic asthma [125].

\section{Role of Bacterial mEV of Dust in Airway Remodeling during Atopic Allergic Asthma}

The inhalation of allergens and other entities in dust is a common exposure contributing to the pathogenesis of asthma in allergic individuals. Indoor dust contains not only house dust mite $\mathrm{Ag}$ as the dominant allergens, but also $\mathrm{mEV}$ components from Gram-negative bacteria derived from the GI tract of humans and pets. Such an occurrence contributes to an expansion of the hygiene hypothesis. This proposes that our changed relationships with infectious agents are a part of Darwinian evolutionary processes that have led to a great increase in some

Exosomes in Allergy and Hypersensitivity diseases of Western civilization, like allergies and particularly asthma.

In homes that are a part of dairy farms, the dust contains mEV LPS from Gram-negative bacteria of the cattle. The LPS-containing $\mathrm{mEV}$ are likely involved in an asthma-protective effect of chronic low-dose exposure to the farm dust. This can happen in children growing up on a dairy farm near the animals, which protects them from allergic rhinitis and asthma [142]. The protective effect depends on $\mathrm{mEV}$ LPS induction of the ubiquitin-modifying enzyme A20 in lung epithelium [143]. Thus, the farming environment protects from allergy by modifying nanovesicle intercellular communication between barrier lung epithelial cells and then DC through the induction of A20 by LPS in mEV. Such a chronic exposure to a very low dose of $\mathrm{mEV}$ LPS in farm dust protected experimental mice from developing asthma in a model induced by house dust mite Ag. The mEV-protected mouse airway epithelial cells produced less cytokines to activate DC, thus suppressing Th2 reactivity to house dust mites.

In contrast, repeated airway administration of LPS $\mathrm{mEV}$ isolated from indoor house dust to mice led to neutrophilic pulmonary inflammation with infiltration of Th1 and Th17 cells [144]. The vesicles were internalized by airway epithelial cells and alveolar macrophages. This process was blocked by treatment with the polymyxin-B antagonist of LPS in the mEV of Gram-negative bacteria [144]. In this study, serum levels of IgG1 Ab reactive with the dust vesicles were significantly higher in atopic children with asthma than in healthy children and those with rhinitis or dermatitis [144]. Thus, nanovesicle intercellular communication, like that mediated by mEV LPS in environmental dust, can be crucial in tipping the balance between the development of Th2 versus Th17-dominated asthma [145]. Importantly, IL-17 is known to recruit and activate neutrophils and thus is an important mediator of chronic inflammation, so in the present context it is another contributor to potential asthmatic airway remodeling.

Interestingly, sphingosine-1-phosphate inhibits murine endotoxin-induced inflammatory lung injury. This is likely due to the formation of exosomes and involves inhibitory G protein-coupled sphingosine-1-phosphate receptors [146] that regulate exosomal maturation in MVB [147]. As mentioned above, the release of exosomes depends on ceramide biosynthesis regulated by neutral sphingomyelinase- 2 and thus can be suppressed by its inhibitor GW4869, both in vitro and in vivo $[76,148]$, as has already been employed in a study on the role of exosomes in allergic airway inflammation in a murine model [76]. 
Yet another possibility was highlighted by the recent demonstration that mEV contain RNA $[14,15]$, and can release this RNA [16] to possibly function or trigger TLR4 stimulation in $\mathrm{mEV}$-induced airway remodeling in asthma. Accordingly, we predict that bacteria-derived $\mathrm{mEV}$ containing LPS and epigenetic effects of their delivered RNAs will be found to be an important causative agent for asthma remodeling. Of related interest, S. aureus-derived $\mathrm{mEV}$, which play a significant role in the pathogenesis of atopic dermatitis [17], have also been shown to induce neutrophilic pulmonary inflammation via both the Th1 and Th17 cell-dependent pathways $[149,150]$. This could be important in chronic phases of allergic asthma and in some forms of nonatopic asthma, with subsequent remodeling.

Taken together, these findings suggest that exosomes derived from endogenous airway stromal cells and infiltrating inflammatory cells of late-phase asthmatic inflammation, and or together with $\mathrm{mEV}$, and possibly bacteria toxins, stimulating the release of lung tissue-derived exosomes, can participate in the sensitization for airway hyperresponsiveness and tissue remodeling changes in allergen-driven chronic asthma. Such a remodeling is particularly difficult to treat clinically, especially using inappropriate antimediator and anti-inflammatory agents aimed at earlier phases. Thus, the new realization of a potential role for exosome delivery of miRNAs in remodeling opens a new pathway that might possibly lead to entirely new and likely more effective therapies aimed at impairing the consequent epigenetic mechanisms of exosome-transferred miRNAs. Also, documentation of the participation of $\mathrm{mEV}$, and possibly TLR agonists, in the evolution of remodeling in allergic asthma might lead to the more vigorous use of antibiotics, perhaps administered to the lung topically in an aerosol, or specific bacterial vaccination, perhaps with $\mathrm{mEV}$, to possibly impede this process, again by analogy with atopic dermatitis.

\section{Exosome RNA Biomarkers for Predicting and Following Allergic Asthma}

The use of miRNAs as biomarkers that are carried in extracellular vesicles from the blood [150], BALF [151] and airway epithelium [152] of asthmatic patients were recently described, and similarly in serum-derived exosomes from mice with asthmatic airway inflammation [153]. In addition, this biomarker information of respiratory tract conditions was collected noninvasively, and very innovatively, by assaying the miRNAs of the exosomes from exhaled breath condensate from the patients. Samples were compared from patients with type I allergic asthma, chronic obstructive pulmonary disease, pulmonary tuberculosis, and from normal individuals [154, 155]. The data showed potential distinctive alterations of miRNA profiles in exhaled exosomes from asthma patients and, very importantly, even those with mild or early disease. Thus, miRNA profiles of exosomes from BALF, airway exhalate and blood might serve as excellent asthma biomarkers, which could be especially useful in the possible early detection of components determined to be predictors of remodeling. If particular exosome miRNAs were known to be such predictors, then perhaps airway aerosol treatments with hybridizing polynucleotide antagonists such as a particular specific anti-miRNA sequence might prevent the process.

It is established that extracellular miRNAs in the blood are carried in exosomes. However, some of the blood miRNAs are transported not by exosomes, but by chaperone hydrophobic proteins, like argonautes and lipoproteins, for similar protection from RNases [156-159]. We found that these nonexosomal miRNAs act to suppress in vivo immune inflammatory responses by associating with exosomes produced by neighboring cells to the target effector cells, and, like those in exosomes [2], were susceptible to anti-miR treatment [7].

In summary, the use of exosomes for the development of useful clinical biomarkers that would aid the early detection of susceptible individuals prone to developing more significant asthma and late tissue remodeling, and the use of entirely new modes of specific therapy based on the inhibition of particular miRNAs with specific antagonists, would be revolutionary. Such new procedures may prevent the progression of airway remodeling from its current nonreversible state and possibly reduce the need for extensive chronic treatment with anti-inflammatory steroids and bronchodilators.

\section{Exosomes in Immune Tolerance and the Suppression of Asthma}

Since miRNAs usually downregulate mRNA translation they often mediate the suppression of immune responses. Therefore, exosomes delivering miRNAs play a particularly prominent role in immunoregulation, mostly in tolerance and suppression. As an example, BALF exosomes (called 'tolerosomes') obtained from donor mice tolerized to olive pollen peptide by the repeated in-
Nazimek/Bryniarski/Askenase 
tranasal administration of a high dose of Ag, significantly suppressed allergic airway reactions when administered to mouse recipients with a model of asthma [160]. The tolerogenic exosomes decreased allergic eosinophil-rich bronchial tissue inflammation and reduced the production of IgE Ab and Th2 cytokines. The observed suppression was most likely Ag nonspecific, since mice pretreated by intranasal administration of BALF-derived exosomes from donors tolerized to the allergen-derived olive pollen peptide were protected from the development of airway allergic inflammation after subsequent sensitization with another allergen, i.e. birch pollen peptide. However, the Ag cross-reactivity between both of the pollen $\mathrm{Ag}$ could possibly occur. In the analogous system of $\mathrm{Ag}$ high-dose tolerance in the Th2-type response described above, the treatment of recipient mice before sensitization with intestinal epithelial cell-derived tolerosomes found in the serum of mice orally tolerized to OVA [161] induced oral tolerance. Furthermore, as a possible example of a relationship between bacterial $\mathrm{mEV}$ and asthma tolerance, neonatal exposure to the enterotoxin superantigen of $S$. aureus augmented the subsequent induction of oral tolerance to OVA in a mouse model of asthma [162]. In contrast, exosomes from an epithelial cell line cultured in the presence of an OVA hydrolysate of peptides with IFN $\gamma$ were not tolerogenic, but instead activated the humoral Ab immune response to OVA [163]. This suggested that such exosomes can tilt a tolerogenic versus immunogenic response by the preincubation of donor cells with specific cytokines. Additionally, cytokines can be transported between cells by nanovesicles. In a neurological system, extracellular vesicles from neural stem cells were shown to be able to transfer IFN $\gamma$ bound to its receptor, in order to activate Stat 1 signaling in the targeted cells [65].

\section{Exosomes of Breast Milk in Allergy and Immunity}

Breast milk contains a rich pool of exosomes carrying numerous immune-related miRNAs that are considered to be involved in the development of immunity and allergic disease responses $[164,165]$. Since miRNAs mediate the inhibition of mRNA translation, they are often involved in immunosuppression, as is thought to be true for those present in the exosomes of breast milk. By definition the miRNAs in these exosomes are protected from the GI tract RNases and other degradative conditions [166]. As mentioned, exosomes, as ancient particles of life, resist many harsh conditions that cells do not survive in, such as the acidic $\mathrm{pH}$ of the stomach $[28,29]$, even down to a pH of 1 [30]. Thus, the miRNAs in breast milk exosomes can survive normal neonatal ingestion to then mediate immunoregulation in the neonate that is related to the microbiome being acquired and the possible development of allergies. It is established that colostrum delivered from the mother to neonate just after birth is rich in IgA $\mathrm{Ab}$ protective against GI tract and skin infectious agents. This provides the infant with the mother's prior humoral $\mathrm{Ab}$ experience. Colostrum is also known to contain exosomes $[167,168]$ that can transfer different immune information, likely regarding cellular immunity that is delivered to the neonate during breast feeding. This is postulated to be related to cell-mediated responses aiding neonatal regulation of the microbiome that the child is acquiring and sharing with the mother. Accordingly, the mother's milk transfers various factors of immunosuppressive functions that likely protect the neonate from overreactivity to the great load of highly stimulatory foreign $\mathrm{Ag}$ of the microbiome they are acquiring. Furthermore, breast milk exosomes also seem to provide protection that is needed for the control of unnecessary and deleterious allergic responses to foreign Ag. This likely pertains particularly to food Ag that are also being encountered for the first time. If not controlled, responses to new microbial Ag and food allergen exposures might lead to clinical hypersensitivity or allergy later in life.

Functional analysis has revealed that the mother's milk exosomes can inhibit T cell production of IL-2 and IFN $\gamma$ following MHC stimulation [169]. In addition, incubation of the milk vesicle preparations with peripheral blood mononuclear cells increased the number of suppressive Foxp $3^{+}$Treg cells. In studies extending these findings, breast milk exosomes were shown to contain functional inhibitory TGF- $\beta$ [170], along with miRNA that can promote thymic Treg cell maturation [171], and that their immunosuppressive action likely inhibits the innate immune functions of macrophages that may be acting as APC [172]. Furthermore, mother's milk exosomes contain miRNA-17, part of the miRNA-17-19 cluster, which is important for the activity of myeloid suppressor cells, as well as miRNA-181a, a modulator of TCR sensitivity to Ag. This acts partly through downregulation of phosphatases, which leads to elevated phosphorylation of intermediate signaling proteins and a consequent reduction of the TCR signaling threshold [173].

In addition, the miRNAs transferred by milk exosomes include miRNA-155 that is a distinctive regulator of $\mathrm{T}$ and $\mathrm{B}$ cell maturation and of the innate immune response [174]. miRNA-155 mediates inhibitory function 
in several other aspects of immune responses, including allergies. Such inhibition is in part due to the miRNA-155 control of the expression of the specific Treg transcription factor Foxp3, and consequent IL-4 signaling, together with Ig class switching to IgE and Fc $\gamma$ RI expression [171]. These findings confirm that a dominant function of breast milk exosomes is to genetically control neonatal immune reactivity, inflammation and likely allergy via the intercellular transfer of miRNAs focused on the epigenetic modulation of cellular immunity relevant to the newly colonizing microbiota of the GI tract and exposure to food allergens. Therefore, isolation and characterization of inhibitory mother's milk-derived exosome-derived miRNAs could then be developed into natural clinical candidate agents mediating completely new therapies for the downregulation of atopic sensitization and Th2 effector immune responses associated with the production of IL-4, IL-5, and IL-13.

Accordingly, natural mother's milk miRNAs may induce pivotal immunoregulatory and epigenetic modifications required for long-term central thymic Treg cell lineage commitment explaining the atopy-protective effect of mother's milk. Since exosomes are poorly immunogenic and miRNAs are universal, this applies to raw allogeneic cow's milk consumption as well [175]. Furthermore, bovine milk components may also target APC in the neonate, since its exosomes have been shown to influence macrophages [172], and this might affect food allergy to milk too. These ideas offer a new option for the prevention of atopic diseases, for example by the addition of physiological amounts of miRNA-155-enriched exosomes into infant formula for mothers that are incapable of breastfeeding. In addition, bovine milk extracellular vesicles may show therapeutic effects since they were found to affect the course of mouse arthritis [176].

However, some studies with breast milk have pointed out that exosomes carrying allergen can in some circumstances augment rather than suppress immune responses, and thus may contribute to the development of allergy in infants. This may explain the higher incidence of neonatal allergy transmission from the mother than the father. Notably, the composition of exosomes in human breast milk differs greatly according to the mother's sensitization status and lifestyle, which can influence the risk of allergy development in breast milk-nourished children [175].

The recent rise in allergic diseases in infants of developed countries may in part be due to the reduced or different microbial exposure during early life and consequent alteration of gut microbiota-derived $\mathrm{mEV} \mathrm{[14],}$ which is relevant to the 'hygiene hypothesis'. Since the microbiota content of the infant's GI tract likely plays a critical role in the maturation and development of the immune system, $\mathrm{mEV}$ from these 'self microorganisms' may possibly contribute to the risk of allergic and immune diseases. Therefore, breast milk feeding may provide important exosomes that can either directly modify the immune response to and composition of the intestinal microflora or influence the host to reduce the development of allergic diseases. Furthermore, mEV of the microbiome may be involved in its important role in the development of the neonatal immune system as well as aspects of the endocrine and nervous systems. Indeed, it was recently demonstrated that exosomes delivered in breast milk can promote the colonization of the newborn intestine with physiological microbial flora, which in turn seems to reduce the risk of allergy development and, thus, is crucially involved in the effects of the microbiome by the release of $\mathrm{mEV}$ or affection of intestinal production of host exosomes that transmit protective miRNAs [177]. Of further interest, it was recently proposed that polymorphisms in susceptibility genes in humans promote inflammatory bowel disease development, causing impaired sensing of protective signals derived by the $\mathrm{mEV}$, which confirms the significant role of microbiome-derived vesicles in the maintenance of immune homeostasis in the digestive system [178].

\section{The Role of Exosomes in Delayed-Type and Contact Hypersensitivity That Can Replace APC Function with Simpler 'Mini-APC' Vesicles}

Delayed-type hypersensitivity (DTH) reactions exemplify mechanistic steps underlying Th1-mediated immune diseases and also defenses against pathogenic intracellular bacteria, fungi, parasites, and some viruses that include intercellular actions of exosomes [89]. Major examples of exosome involvement in cell-mediated immunity are represented by DC that were pulsed with native $\mathrm{Ag}$ of infectious agents $[88,179]$. Then they are used as noncellular potent vaccines substituting for DC. Accordingly, DC-derived nanovesicles able to present peptide/ MHC complexes, and thereby acting like parental DC, were used to induce immune responses against tumor cells [90-92], and also the inhibition of inflammatory responses to LPS [180]. We are not yet aware of the use of allergen-pulsed DC or other APC to produce Ag-presenting exosomes to desensitize against allergens. Instead this is traditionally done by administration of ascending doses
Nazimek/Bryniarski/Askenase 
of soluble Ag in buffer for the induction of tolerance. However, this can definitely be expected. Such a miniAPC approach should be far safer, since allergen peptides are being given in a form that should not readily trigger $\mathrm{IgE} /$ mast cell responses that are more directed at the specificity of IgE to conformational determinants of usually given native allergens. Furthermore, such a mini-APC vesicle method will likely be far more effective due to the direct facilitation of Ag presentation not requiring the processing of native allergen. As an example, exosomes derived from OVA-pulsed mouse bone marrow DC express OVA peptide complexed in MHC. Administration of this exosome peptide-MHC complex leads to the polarization of immune response towards the Th1 phenotype [82], and thus may be effective clinically in treating Th2mediated allergic diseases.

As noted above, exosome-like mEV can influence cell-mediated immune responses as agents of the microbiome that shape and modulate the immune response. This approach takes advantage of the fact that mEV can be manipulated for their immunogenic contents for utilization as potent pathogen-free vaccines for immunizing humans and animals against infectious agents. Accordingly, DC that are pulsed with Toxoplasma gondii [181] release into the culture supernatant immunostimulatory exosomes that can replace DC. Additionally, Escherichia coli release mEV [182], which, after injection into mice, are readily taken up by APC to efficiently stimulate a specific Th1-dependent immune response that prevents bacterial infections and most probably allergy development as well.

On the other hand, DC can be modified to produce immunosuppressive exosomes. Thus, administration of exosomes released by mouse DC genetically modified to express inhibitory Fas ligand resulted in the suppression of DTH elicited in mice immunized by intradermal injection of OVA or keyhole limpet hemocyanin (KLH) Ag emulsified with Freund's complete adjuvant [183]. Similarly, exosomes derived from cultured DC stimulated with IL-4 [184] or IL-10 [185] inhibited DTH induced by $\mathrm{KLH}$ with adjuvant. This effect was found to be dependent on the expression of the costimulatory molecule B7 (CD80/87) on the cytokine-treated DC [185]. It was concluded that B7, but not PD-L1/L2, on the surface of IL10 -treated $\mathrm{DC}$ and their derived exosomes play a critical role in the observed immunosuppressive functions.

In related in vivo studies, the systemic injection of IL10-containing DC-derived exosomes suppressed the onset of murine collagen-induced arthritis (CIA) and reduced the severity of already established arthritis [186].
Taken together, these data suggest that DC secrete exosomes that can be tailored to suppress inflammatory and autoimmune responses.

In a further study, indoleamine 2,3-dioxygenase (IDO), which is a tryptophan-degrading enzyme important for immune regulation and tolerance maintenance, was expressed in DC and their exosomes inhibited DTH effector T cells by depleting them of essential tryptophan and/or by producing toxic metabolites, as well as by generating Treg cells [187]. Accordingly, exosomes derived from these IDO-positive DC suppressed DTH and CIA. The suppressive effects were partially dependent on B7 costimulatory molecules. In addition, the gene transfer of CTLA-4 Ig to DC resulted in the induction of IDO in the DC releasing exosomes that were able to reduce inflammation in an IDO-dependent manner [187]. These results demonstrate that both types of IDO-expressing DCderived exosomes are immunosuppressive and anti-inflammatory, and consequently are able to reverse established arthritis. Therefore, exosomes from IDOpositive DC may represent a novel therapy for rheumatoid arthritis, and highlight studies showing that altered exosomes from in vitro manipulated DC can significantly influence DTH and related clinical disease models, like CIA.

As noted above, rats fed with OVA develop a tolerogenic activity in serum that can transfer tolerance to OVA and suppression when given at the time of induction of an immune response, and more over can abolish an established DTH response in the recipients, as well as their humoral IgG responses. The mechanism possibly involves demonstrated inhibitory exosomes ('tolerosomes') acting through $\mathrm{CD} 25^{+}$Treg cells and produced by GI epithelial cells from rats undergoing the induction of oral tolerance to OVA. Furthermore, this exosome-induced tolerance seems to be $\mathrm{MHC}$ restricted, and probably Ag nonspecific, since tolerosomes from animals fed with OVA suppress DTH induced with OVA or with human serum albumin $[188,189]$. In contrast, exosomes from the culture supernatant of a tumor cell line manipulated genetically to express OVA, when injected at the time of DTH elicitation, were able to suppress mouse OVA-specific DTH induced as above, but not DTH induced by a $\mathrm{KLH}$-adjuvant mixture, and thus acted in an Ag-specific manner [190]. As noted, tumor cell-derived exosomes usually contain tumor $\mathrm{Ag}$ and have been used as miniAPC to stimulate antitumor immune responses [90-92]. However, it is unclear if the tumor-derived exosomes can actually facilitate Ag-specific tumor immune evasion. Here, the tumor-derived OVA-expressing exosomes 
were internalized by $\mathrm{CD} 11 \mathrm{c}^{+} \mathrm{DC}$ and transported to the draining lymph nodes to likely induce TGF- $\beta_{1^{-}}$and IL4-producing Ts cells that seemed to modulate the APC to express an Ag-specific inhibitory function [190]. Furthermore, exosomes isolated from the plasma of mice immunized to KLH, but not from naive mice or OVA-immunized mice, could suppress KLH and not OVA-specific $\mathrm{DTH}$. The effect was mediated by $\mathrm{MHC}$ class $\mathrm{II}^{+}$, Fas ligand $^{+}, \mathrm{CD}_{11} \mathrm{~b}^{+}$, but $\mathrm{CD} 11 \mathrm{c}^{-}$plasma exosomes. In part these were dependent on the presence of Fas ligand on the exosomes and Fas on the recipient mouse cells [191]. These results suggest that plasma exosomes likely produced by APC and expressing CD11b and MHC class II complexed with tumor cell-derived peptides can suppress the immune response in a peptide $\mathrm{Ag} / \mathrm{MHC}$-specific manner partly through Fas/FasL interactions.

\section{$\mathrm{CD8}^{+}$Suppressor T Cell Exosome Ag Specifically Suppresses CHS and DTH by Delivering Inhibitory miRNA-150}

The current research of our laboratories aims to investigate the detailed mechanisms of Ag-specific suppression of mouse hapten-induced CHS, as well as DTH that is induced by the intradermal injection of protein Ag without an adjuvant. CHS is considered to be a model that is relevant to human allergic contact dermatitis. Both are also considered to depend on mechanisms underlying cell-mediated immune responses to proteins in a variety of diseases, such as asthma, atopic dermatitis and various autoimmune conditions. We have reinvestigated the previously observed suppression of CHS by an enigmatic Ag-specific factor secreted into culture supernatant by Ts lymphocytes harvested from mice tolerized by intravenous injection of high doses of $\mathrm{Ag}$. This led to the discovery of suppressive exosomes carrying inhibitory miRNA-150 that are surface coated with $\mathrm{Ab}$ light chains responsible for their Ag specificity $[2,192]$. Thus, we demonstrated that this enigmatic Agspecific suppressor factor from mice rendered Ag specifically tolerant by the intravenous administration of a high dose of hapten Ag conjugated to autologous red blood cells, and subsequently immunized for CHS induced by the same hapten, was produced by $\mathrm{CD} 8^{+} \mathrm{Ts}$ cells as exosomes. These exosomes act by carrying and subsequently delivering inhibitory miRNA-150 Ag specifically, due to their surface coating of Ab light chains, and interestingly not heavy chains or whole $\mathrm{Ab}[2]$. The suppressive exosomes could be isolated from either plasma of the tolerized animals or from culture supernatant of the Ts cells harvested from tolerized mouse spleen and peripheral lymph nodes $[2,192]$. Critically, the inhibitory activity of the miRNA-150 was blocked by preincubation of the suppressive exosomes with an antagonist of miRNA-150, a polynucleotide of reverse sequence, i.e. anti-miR-150, compared to several controls [2].

The most important proofs were provided by experiments with miRNA- $150^{-/-}$mice. Although appearing normal and able to be fully sensitized for the elicitation of $\mathrm{CHS}$, these animals could not be tolerized, and exosomes from these unsuccessfully tolerized mice were lacking a suppressive function in vivo in CHS and in vitro blocking of the IL-2 receptivity of the T cell line [2]. Also very crucially, in vitro supplementation of these nonsuppressive exosomes from the miRNA-150 ${ }^{-/-}$mice tolerized with a high dose of hapten Ag, with synthetic miRNA-150 agonist, rendered them suppressive [2, 7]. Taken together, these findings show definitively that miRNA-150 delivered by the Ts cell-derived exosomes is the crucial mediator of the suppression. Further, that surface Ab light chains are responsible for the Ag-specificity of their suppression. The $\mathrm{CD} 8^{+}$Ts cells producing the inhibitory exosomes are Foxp $3^{-}$[2], and thus are not conventional Treg cells, but instead originate from a separate lineage of regulatory cells that act to suppress CHS and DTH responses in vivo and in vitro [2].

\section{A Special Small Subset of B Cells Produces the Ag-Specific Ab Light Chains That Coat the Suppressive Exosomes}

The Ts cell-derived exosomes are able to act as a preventive as well as therapeutic agent by inhibiting, respectively, the sensitization and elicitation of CHS, and by the alleviation of its symptoms [193]. However, the Ts cell exosomes are not nonspecifically pan-suppressive, since, while suppressing the Th1 effector cells mediating the classical late phase of CHS and DTH, they do not inhibit the required early phase mediated by B1a cells. These B1a cells are stimulated by IL-4 released rapidly after sensitization (by only $18 \mathrm{~min}$ ) by hepatic iNKT cells [108]. These apparently are activated by glycolipid Ag swiftly released at the cutaneous sensitization site to then seemingly migrate to the liver to preferentially target hepatic iNKT cells [194]. As stated above, miRNA-150 loaded exosomes act in a strictly Ag-specific manner. Definitive dual reciprocal testing
16

Int Arch Allergy Immunol 2016;171:1-26 DOI: $10.1159 / 000449249$
Nazimek/Bryniarski/Askenase 
showed that exosomes obtained from mice tolerized to the trinitrophenyl (TNP) hapten suppressed only TNPinduced CHS, but not oxazolone (OX)-induced CHS effector cells, and, conversely, exosomes from mice tolerized to OX suppressed only CHS effector cells induced with the OX hapten, but not with TNP [2]. This unusual Ag-specificity has been unraveled by the discovery that the Ts cell-derived exosomes have a surface coating of hapten Ag-specific Ab light chains derived from B1a cells accompanying the $\mathrm{CD} 8^{+}$Ts cells. These $\mathrm{B} 1 \mathrm{a}$ cells are activated by hapten-self complexes induced by the application of the relevant hapten on mouse skin, which completes the tolerogenic procedure [2]. The strict Ag specificity of the participating B1a cell subpopulation is due to activation-induced deaminase (AID), a nuclear mutating enzyme, which acted on the DNA of these cells prior to the immunization to cause mutations in the Ig $\mathrm{V}$ region genes, thus encoding the Ag-specific combining sites of Ab heavy and light chains [109, 195, 196]. This compares to the usual strictly germ line Vregion DNA sequences without mutations in the majority of typical B1a cells that are not acted on by AID, and produce so-called natural $\mathrm{Ab}$. However, recent single cell sequencing of Ig V regions of developing B1a cells has shown that many of these cells, more than expected by prior information, are acted on by AID [197]. However, the processes stimulating the occurrence of AIDdependent mutations before immunization require further investigation. They do not involve prior sensitizing interactions with the microbiome, as they occur in germ-free animals. Thus, the presumed Ag activation that stimulated this subpopulation of B1a cells did not come from the standard external bacterial-, viral- or parasite-derived foreign Ag, but likely from unknown endogenous Ag [197].

Characteristically, the special B1a cells, having only a few Ig V region mutations mediated by AID that account for their strict Ag specificity, are able to respond within minutes of hapten-self primary skin immunization, documented to occur in separate systems by just $18 \mathrm{~min}$ [108], $30 \mathrm{~min}$ [109] or $1 \mathrm{~h}$ [198] after the original skin sensitization. As a consequence, the exosome-sensitizing $\mathrm{Ab}$ light chains with few mutations are of low affinity for Ag, compared to their associated isolated heavy chains or the parental whole Ab. However, multiple adjacent arrangement on the exosome surface likely results in their greater Ag avidity, sufficient to manifest the observed strict dual reciprocal Ag specificity of the suppressive exosomes [2]. Altogether, the suppressive exosomes that inhibit allergic cutaneous CHS are an unusual and unique

Exosomes in Allergy and Hypersensitivity product of components from both $\mathrm{T}$ cells (the miRNA150-containing exosomes) and B cells (the exosome coating $\mathrm{Ab}$ light chains).

The crucial experiment determining the role of $\mathrm{Ab}$ light chains coating the suppressive exosomes attempted to induce typical $\mathrm{Ag}$ high dose tolerization in pan-Ig-deficient $\mathrm{JH}^{-l-}$ mice. These mice lack $\mathrm{Ab}$ and, therefore, $\mathrm{Ab}$ light chains to coat the exosomes. Thus, cutaneous immunization for CHS in $\mathrm{JH}^{-/-}$mice previously tolerized with a high dose of Ag was not suppressed and their exosomes were not active [2]. Very importantly, suppression was restored by the coating of these nonsuppressive exosomes from tolerized $\mathrm{JH}^{-1-}$ mice with monoclonal $\mathrm{Ab}$ light chains [2]. Of related translational clinical significance, in our prior work on immediate hypersensitivity based on models of CHS [199] and asthma [200] induced by cutaneous sensitization with hapten or protein [201], the rapid activation of the small subpopulation of Ag-specific special B1a cells induced early after immunization was observed in all of these instances. Their activation resulted in the production of Ag-specific IgM Ab and the Ag-specific Ab light chains that coat the Ts cell-derived exosomes. These have the additional ability to sensitize cells, so far principally mast cells, by surface coating for mediator release when $\mathrm{Ag}$ is added in an analogous manner to IgE Ab [202].

Regarding the suppressor exosomes, Ag-specific $\mathrm{Ab}$ free light chains [2] are produced by previously activated B1a cells and have low numbers of AID-mediated V-region mutations $[109,196]$. They bind to the surface of $\mathrm{CD}^{+}{ }^{+}$Ts cell-derived exosomes in a manner that keeps their combining sites available and allows quite an Agspecific function [2]. Note that tests in Fc receptor-deficient mice showed that these receptors are not involved in Ab light chain binding [202]. This is expected since they have no Fc portion. Instead, this binding may depend on surface lipid changes in the membrane of 'activated' exosomes $[2,7]$, or by other unknown processes that are induced by tolerization or immunization. In contrast, exosomes from spleen and lymph nodes of nonimmunized mice do not have the ability to bind free $\mathrm{Ab}$ light chains. It is important to note that in related clinical work, it has been shown that various human leukocytes, like T cells, B cells and monocytes, can bind free Ab light chains $[203,204]$. It was shown that this depends on cell surface lipids [204, 205]. Therefore, this subpopulation of B1a cells, stimulated by hapten contact skin application as the final step in the tolerance procedure or for induction of $\mathrm{CHS}$, or the analogous maneuver of intradermal injection of OVA protein Ag to produce toler- 
ance to this protein, is responsible for the generation of hapten or protein Ag-specific Ab for the coating of Ts cell-derived 'activated' exosomes in mice undergoing Ag high-dose tolerization.

\section{Free miRNAs That Are Not in Exosomes Also Suppress Ag Specificity by Final Association with Ag-Specific Exosomes}

In other studies we defined an alternate pathway of suppression mediated by miRNA-150 present in a mixture of miRNAs that are free of exosomes. This mixture of extracellular RNAs (exRNA) was obtained by phenol chloroform extraction of the exosomes derived from the Ag-tolerized mice. miRNAs free of exosomes are also protected from RNases, by complexing with a hydrophobic chaperone, like an argonaute protein [7, 156159]. Interestingly, among the vast excess of other free RNAs and miRNAs in the exRNA mixture that are Ag nonspecific, miRNA-150 nonetheless inhibited CHS effector cells Ag specifically, as had Ts cell-derived exosomes [2]. This unusual finding of exRNAs acting Ag specifically in the absence of exosomes was unraveled. We demonstrated that the miRNAs became associated with Ag-specific exosomes produced by the Ag-specific $\mathrm{B} 1 \mathrm{a}$ cells present in the mixture of CHS effector cells. The B1 a cells made exosomes expressing surface Ab-like $B$ cell Ag receptors (BCR). This mixed effector cell population also contained the Ag-specific CHS effector T cells and APC. These were then suppressed by the Agspecific B1a cell-derived exosomes that had become associated with the miRNA [7].

These findings led to speculation that this represents an alternate pathway of Ag-specific targeting by freely circulating functional miRNA not contained in exosomes to regulate CHS effector $\mathrm{T}$ cells. In this case the miRNA among the exosome-free exRNA can be delivered to function in allergic CHS and perhaps in other responses by its association with such B1a cell-derived, Ag-specific, originally nonsuppressive exosomes. These exosomes were originally shown not to carry miRNA-150, but then were induced to gain it from the associating mixture of free exRNAs. Ag specificity of the exosome-associated miRNA suppressive activity results from the presence of $\mathrm{BCR}$ on the B1a cell-derived exosome surface. This allows for their specific delivery to affect Ag-specific T cells in the CHS-effector cell mixture.

The major miRNA fraction in the human circulation is free of exosomes, and instead is also protected from numerous RNases by complexing with chaperones, like argonautes and lipoproteins. This suggests that these miRNAs may similarly act by this alternative pathway of associating with or transfecting exosomes released by either cells neighboring the target cell population, or possibly even by the target cells themselves.

Overall, this is the first demonstration that miRNA free of exosomes can be functional and gain Ag-specific cell targeting to affect genetic function. This alternate pathway appears to be the only natural mechanism yet described for passing functional free extracellular miRNA between cells. This pathway of free exRNA intercellular transfer contrasts with the classical donor cell release of RNA-containing and cell-targeting exosomes. Since significant amounts of circulating exRNA are not in exosomes, these findings likely have important biological and immunological significance, and may be relevant to both the pathogenesis and treatment of diseases.

\section{Determination That miRNA-150 Was Responsible for Exosome Suppression by Exploiting Their Ag Specificity}

The discovery that coating of the suppressive exosomes with Ag-specific Ab light chains was responsible for their Ag specificity then led to the discovery of miRNA-150 as the crucial delivered inhibitory molecule. The Ag-specific Ab light chains were judged to enable Agspecific binding of the suppressive exosomes. This allowed for their fractionation using Ag-affinity column chromatography [2]. The Ag-binding exosomes had all the suppressive activity [2]. Processing of these Ag-binding exosomes, versus the $\mathrm{Ag}$ nonbinding exosomes, to mRNA, with further conversion to cDNA, and then DNA deep sequencing with subsequent bioinformatic analysis suggested consideration of miRNA-150 as the important inhibitory molecule in the Ag-specific suppressive exosomes. This was verified by the blocking of exosome suppression with the antisense polynucleotide of miRNA-150 (anti-miR-150), compared to numerous controls. Final definitive confirmation was shown by experiments in Ag-tolerized miRNA- $150^{-/-}$mice. The crucial experiment showed that association of the nonsuppressive exosomes from the unsuccessfully tolerized miRNA $-150^{-/-}$mice with miRNA-150 rendered them suppressive, in comparison to several controls as described above. This constituted a definitive proof that miRNA-150 is the crucial inhibitory molecule carried by the exosomes that is responsible for the suppression of allergic cutaneous $\mathrm{CHS}$.
18

Int Arch Allergy Immunol 2016;171:1-26 DOI: $10.1159 / 000449249$
Nazimek/Bryniarski/Askenase 


\section{APC Are the Target of the Ag-Specific Suppressive Exosomes}

Further experiments showed that the inhibited CHS effector $\mathrm{T}$ cells are not the direct target of the suppressive exosomes, but rather their companion Ag-presenting cells, represented in our initial experiments by Ag-carrying macrophages. These APC are altered to become suppressive by the delivery of exosome miRNA-150 to then be able to Ag-specifically suppress companion Ag-specific CHSeffector T cells that recognize $\mathrm{Ag} / \mathrm{MHC}$ complexes on the APC [206]. Finally, as confirmation of the above formulation, depletion of macrophages from the total CHS-effector cell population prior to in vitro incubation with the suppressive exosomes that precedes the adoptive cell transfer of CHS abolishes the suppressive action of the Ts cell exosome-delivered miRNA-150 on the CHS effector cell mixture. This observation confirms that Ag-presenting macrophages are essential for transferring the subsequent suppressive signal of a yet unknown nature [206].

In current follow-up studies employing DTH induced with OVA without an adjuvant we have observed similar tolerance, allowing us to attempt to confirm the hypothesis that this mechanism requires the binding of OVA peptides on the APC surface by the Ab light chains on the suppressive exosomes. Accordingly, our preliminary evidence shows that the Ts cell exosomes inhibition of CHS involves the binding of $\mathrm{Ag}$ peptide determinants in the peptide/MHC complex on the surface of the APC by the Ag-specific Ab light chains on the exosome surface. This specific binding likely allows for internalization of the suppressive exosomes for delivery of their miRNA-150 into the Ag-presenting macrophages to tilt their gene function towards a suppressive pathway to inhibit the CHS effector T cells. Further preliminary data suggest that the Ag-presenting macrophages that received the Ts cell exosomes may suppress the CHS effector T cells via the release of secondary suppressive exosomes. These secondary vesicles as a part of a suppressive exosome cascade finally target the CHS effector T lymphocytes, leading to the inhibition of their function. Currently, the exact mechanism of the Ag-specific, miRNA-150-mediated suppression by the $\mathrm{CD}^{+}$Ts cell-derived exosomes affecting Ag-presenting macrophages to inhibit effector $\mathrm{T}$ cells is the focus of our research. In this regard, in a helper T cell system, pretreatment of Ag-primed macrophages with the Ts cell-derived, Ag-specific exosomes, as in the CHS suppression system above, results in the reduction of helper T cell-dependent, macrophage-mediated induction of $\mathrm{B}$ cell $\mathrm{Ab}$ responses to corpuscular Ag [206]. Ad- ditionally, the treatment of macrophages with suppressive exosomes causes the enhancement of the generation of reactive oxygen intermediates [207]. On the other hand, the mechanism of action of the suppressive exosome miRNA-150 cargo may depend on cytokine responsiveness of the final T cell targets. Accordingly, the suppressive exosomes or the mixed miRNA in their phenol chloroform extracts, or even miRNA-150 alone, inhibit the in vitro responsiveness of HT-2 cells, a T cell line, to IL-2 [2, 7]. In contrast, exosomes derived from lymphoid cells of unsuccessfully tolerized miRNA- $150^{-/-}$mice are inactive in this model and their suppressive activity is restored by the addition of miRNA-150 itself [2]. These additional findings suggest that the mechanisms enumerated above, acting alone or together, may play a role in the effector $\mathrm{T}$ cell suppression begun by the $\mathrm{CD}^{+} \mathrm{Ts}$ cell-derived primary exosomes delivering inhibitory miRNA-150 $[2,7]$.

Additional preliminary data show that we are able to similarly induce DTH by intradermal injection of soluble casein Ag from milk, and activate similar Ag-specific suppression mediated by exosomal miRNA-150. Note that clinical observations suggest that hypersensitivity to casein is an aspect of food allergy to milk products that likely consists of a mixture of a type I allergic response mediated by food Ag-specific IgE Ab, and an additional possible DTH-like component. Therefore, this new technology of established procedures for the dissection of biological properties of functional miRNA carried by suppressive exosomes may enable us to examine and perhaps alter immunoregulatory pathways in food allergy to milk products in a new molecular way.

Thus, overall, our data have significant translational potential for a greater understanding and the possible construction of new therapies for diverse clinical allergic and immunological diseases based on the newly recognized, diverse and complex intercellular communications mediated by extracellular exosomes released by the involved cells, delivering RNAs and proteins to alter functions of acceptor cells involved in allergies and hypersensitivities.

\section{Concluding Remarks}

The pathogenesis of allergic and hypersensitivity responses relevant to human diseases appears to be significantly influenced by various exosome-dependent mechanisms. This principally involves the exchange of functional RNA between cells that are nearby or at a distance. This leads us to the following conclusions. 
Firstly, appreciation of novel near or distant exosome release to mediate functional exchanges, along with established intercellular communication pathways via cytokines, provides new reasons to more strongly consider allergy and hypersensitivity responses in vivo in preference to in vitro, i.e. in vivo veritas. This leads to a preference for in vivo and ex vivo experiments in order to more fully appreciate the undoubtedly exosome-mediated interactions between immune and allergy-mediating cells, and the various stromal cells in their microenvironment, as well as other more distant cells that also send RNA genetic instructions via the circulation (fig. 1).

Secondly, it seems fairly certain that there will be new types of diagnostic approaches to allergic and hypersensitivity diseases involving the analysis of the RNAome and proteome of extracellular vesicles by which genetic instructions are delivered to other cells. These instructive RNAs either may or may not be carried in exosomes in the peripheral circulation or body fluids, like the BALF, and interestingly may even be present in breath exhalate.

Thirdly, the understanding of allergic and hypersensitivity diseases will undoubtedly be advanced when integrating these newly recognized exosome intercellular exchange processes into prior findings and constructs. Thus, this new knowledge should lead to the develop- ment of new preventive and therapeutic strategies beyond conventional modes of regulating and attenuating the immune response to specific allergens and Ag.

Fourthly, our work and other studies have determined that therapeutic exosomes are biologically active after delivery via different routes that were not considered previously. Since exosomes are natural and physiological, they can resist hostile environments, can have long-lasting effects and can penetrate tissue barriers that do not permit the transit of cells. These possibilities include therapeutic approaches far more tolerable to the patient than routine allergy shots. Such potential exosome therapies involve essentially cell-free, noninvasive approaches, with new routes of administration, such as oral, nasal, or inhaled. For the first time there is a real prospect of being able to specifically alter cell functions genetically in a physiological manner. This would be a huge and significant advance with profound clinical consequences.

\section{Acknowledgements}

This work was supported by NIH grants to P.W.A (AI-59801, AI-07174, AI-76366-02, AI-1053786 and U54 DA036134) and by grants from the Polish National Scientific Centre (2013/09/N/ NZ6/00753 to K.N. and 2013/11/B/NZ6/02041 to K.B.).

\section{References}

1 Choudhuri K, Llodrá J, Roth EW, Tsai J, Gordo S, Wucherpfennig KW, Kam LC, Stokes DL, Dustin ML: Polarized release of T-cellreceptor-enriched microvesicles at the immunological synapse. Nature 2014;507:118-123.

2 Bryniarski K, Ptak W, Jayakumar A, Pullmann K, Caplan MJ, Chairoungdua A, Lu J, Adams BD, Sikora E, Nazimek K, Marquez S, Kleinstein SH, Sangwung P, Iwakiri Y, Delgato $\mathrm{E}$, Redegeld F, Blokhuis BR, Wojcikowski J, Daniel AW, Groot Kormelink T, Askenase PW: Antigen-specific, antibody-coated, exosome-like nanovesicles deliver suppressor T-cell microRNA-150 to effector T cells to inhibit contact sensitivity. J Allergy Clin Immunol 2013;132:170-181.e9.

3 Raposo G, Stoorvogel W: Extracellular vesicles: exosomes, microvesicles, and friends. J Cell Biol 2013;200:373-383.

4 Théry C: Exosomes: secreted vesicles and intercellular communications. F1000 Biol Rep 2011;3:15.

5 Bobrie A, Colombo M, Krumeich S, Raposo G, Théry C: Diverse subpopulations of vesicles secreted by different intracellular mechanisms are present in exosome preparations obtained by differential ultracentrifugation. J Extracell Vesicles 2012;1:18397.
6 Smith ZJ, Lee C, Rojalin T, Carney RP, Hazari S, Knudson A, Lam K, Saari H, Ibañez EL, Viitala T, Laaksonen T, Yliperttula M, Wachsmann-Hogiu S: Single exosome study reveals subpopulations distributed among cell lines with variability related to membrane content. J Extracell Vesicles 2015;4:28533.

7 Bryniarski K, Ptak W, Martin E, Nazimek K, Szczepanik M, Sanak M, Askenase PW: Free extracellular miRNA functionally targets cells by transfecting exosomes from their companion cells. PLoS One 2015;10:e0122991.

8 Conde-Vancells J, Rodriguez-Suarez E, Embade N, Gil D, Matthiesen R, Valle M, Elortza F, Lu SC, Mato JM, Falcon-Perez JM: Characterization and comprehensive proteome profiling of exosomes secreted by hepatocytes. J Proteome Res 2008;7:5157-5166.

9 Ogawa Y, Taketomi Y, Murakami M, Tsujimoto M, Yanoshita R: Small RNA transcriptomes of two types of exosomes in human whole saliva determined by next generation sequencing. Biol Pharm Bull 2013;36:66-75.

10 Arita S, Baba E, Shibata Y, Niiro H, Shimoda S, Isobe T, Kusaba H, Nakano S, Harada M: B cell activation regulates exosomal HLA production. Eur J Immunol 2008;38:1423-1434.
11 Mfunyi CM, Vaillancourt M, Vitry J, Nsimba Batomene TR, Posvandzic A, Lambert AA, Gilbert C: Exosome release following activation of the dendritic cell immunoreceptor: a potential role in HIV-1 pathogenesis. Virology 2015;484:103-112.

12 Kulp A, Kuehn MJ: Biological functions and biogenesis of secreted bacterial outer membrane vesicles. Annu Rev Microbiol 2010;64: 163-184.

13 Schwechheimer C, Kuehn MJ: Outer-membrane vesicles from Gram-negative bacteria: biogenesis and functions. Nat Rev Microbiol 2015;13:605-619.

14 Tyrer PC, Frizelle FA, Keenan JI: Escherichia coli-derived outer membrane vesicles are genotoxic to human enterocyte-like cells. Infect Agent Cancer 2014;10:2.

15 Ghosal A, Upadhyaya BB, Fritz JV, HeintzBuschart A, Desai MS, Yusuf D, Huang D, Baumuratov A, Wang K, Galas D, Wilmes P: The extracellular RNA complement of Escherichia coli. Microbiologyopen DOI: 10.1002/ mbo3.235.

16 Sjöström AE, Sandblad L, Uhlin BE, Wai SN: Membrane vesicle-mediated release of bacterial RNA. Sci Rep 2015;5:15329. 
17 Hong SW, Kim MR, Lee EY, Kim JH, Kim YS, Jeon SG, Yang JM, Lee BJ, Pyun BY, Gho YS, Kim YK: Extracellular vesicles derived from Staphylococcus aureus induce atopic dermatitis-like skin inflammation. Allergy 2011;66: 351-359.

18 Gehrmann U, Qazi KR, Johansson C, Hultenby K, Karlsson M, Lundeberg L, Gabrielsson S, Scheynius A: Nanovesicles from Malassezia sympodialis and host exosomes induce cytokine responses - novel mechanisms for hostmicrobe interactions in atopic eczema. PLoS One 2011;6:e21480.

19 Kahlert C, Melo SA, Protopopov A, Tang J, Seth S, Koch M, Zhang J, Weitz J, Chin L, Futreal A, Kalluri R: Identification of double stranded genomic DNA spanning all chromosomes with mutated KRAS and p53 DNA in the serum exosomes of patients with pancreatic cancer. J Biol Chem 2014;289:38693875.

20 San Lucas FA, Allenson K, Bernard V, Castillo J, Kim D, Ellis K, Ehli EA, Davies GE, Petersen JL, Li D, Wolff R, Katz M, Varadhachary G, Wistuba I, Maitra A, Alvarez H: Minimally invasive genomic and transcriptomic profiling of visceral cancers by nextgeneration sequencing of circulating exosomes. Ann Oncol 2016;27:635-641.

21 Thakur BK, Zhang H, Becker A, Matei I, Huang Y, Costa-Silva B, Zheng Y, Hoshino A, Brazier H, Xiang J, Williams C, RodriguezBarrueco R, Silva JM, Zhang W, Hearn S, Elemento O, Paknejad N, Manova-Todorova K, Welte K, Bromberg J, Peinado H, Lyden D: Double-stranded DNA in exosomes: a novel biomarker in cancer detection. Cell Res 2014; 24:766-769.

22 Camussi G, Deregibus MC, Cantaluppi V: Role of stem-cell-derived microvesicles in the paracrine action of stem cells. Biochem Soc Trans 2013;41:283-287.

23 Camussi G, Deregibus MC, Tetta C: Paracrine/endocrine mechanism of stem cells on kidney repair: role of microvesicle-mediated transfer of genetic information. Curr Opin Nephrol Hypertens 2010;19:7-12.

24 Rager TM, Olson JK, Zhou Y, Wang Y, Besner GE: Exosomes secreted from bone marrowderived mesenchymal stem cells protect the intestines from experimental necrotizing enterocolitis. J Pediatr Surg 2016;51.

25 Xin H, Li Y, Cui Y, Yang JJ, Zhang ZG, Chopp $\mathrm{M}$ : Systemic administration of exosomes released from mesenchymal stromal cells promote functional recovery and neurovascular plasticity after stroke in rats. J Cereb Blood Flow Metab 2013;33:1711-1715.

26 Lou G, Song X, Yang F, Wu S, Wang J, Chen $\mathrm{Z}$, Liu Y: Exosomes derived from miR122-modified adipose tissue-derived MSCs increase chemosensitivity of hepatocellular carcinoma. J Hematol Oncol 2015;8:122.
27 Xin H, Li Y, Liu Z, Wang X, Shang X, Cui Y, Zhang ZG, Chopp M: MiR-133b promotes neural plasticity and functional recovery after treatment of stroke with multipotent mesenchymal stromal cells in rats via transfer of exosome-enriched extracellular particles. Stem Cells 2013;31:2737-2746.

28 Ban JJ, Lee M, Im W, Kim M: Low pH increases the yield of exosome isolation. Biochem Biophys Res Commun 2015;461:76-79.

29 Parolini I, Federici C, Raggi C, Lugini L, Palleschi S, De Milito A, Coscia C, Lessi E, Logozzi M, Molinari A, Colone M, Tatti M, Sargiacomo M, Fais S: Microenvironmental $\mathrm{pH}$ is a key factor for exosome traffic in tumor cells. J Biol Chem 2009;284:34211-34222.

30 Kosaka N, Izumi H, Sekine K, Ochiya T: microRNA as a new immune-regulatory agent in breast milk. Silence 2010;1:1-8.

31 Blanc L, Liu J, Vidal M, Chasis JA, An X, Mohandas $\mathrm{N}$ : The water channel aquaporin-1 partitions into exosomes during reticulocyte maturation: implication for the regulation of cell volume. Blood 2009;114:3928-3934.

32 Hamzah M, Braun R, Eldridge M: Exosomes secreted by mesenchymal stem cells prevent hyperoxia-induced lung injury in newborn rat. Crit Care Med 2014;42(suppl 1):A1531.

33 King HW, Michael MZ, Gleadl JM: Hypoxic enhancement of exosome release by breast cancer cells. BMC Cancer 2012;12:421.

34 Admyre C, Telemo E, Almqvist N, Lotvall J, Lahesmaa R, Scheynius A, Gabrielsson S: Exosomes - nanovesicles with possible roles in allergic inflammation. Allergy 2008;63:404-408.

35 Camussi G, Deregibus MC, Bruno S, Grange C, Fonsato V, Tetta, C: Exosome/microvesicle-mediated epigenetic reprogramming of cells. Am J Cancer Res 2011;1:98-110.

36 Ridder K, Keller S, Dams M, Rupp AK, Schlaudraff J, Turco DD, Starmann J, Macas J, Karpova D, Devraj K, Depboylu C, Landfried B, Arnold B, Plate KH, Höglinger G, Sültmann H, Altevogt P, Momma S: Extracellular vesicle-mediated transfer of genetic information between the hematopoietic system and the brain in response to inflammation. PLoS Biol 2014;12:e1001874.

37 Stoorvogel W: Functional transfer of microRNA by exosomes. Blood 2012;119:646-648.

38 Valadi H, Ekstrom K, Bossios A, Sjostrand M, Lee JJ, Lotvall JO: Exosome-mediated transfer of mRNAs and microRNAs is a novel mechanism of genetic exchange between cells. Nat Cell Biol 2007;9:654-672.

39 van Balkom BW, de Jong OG, Smits M, Brummelman J, den Ouden K, de Bree PM, Eijndhoven MA, Pegtel DM, Stoorvogel W, Würdinger T, Verhaar MC: Endothelial cells require miR-214 to secrete exosomes that suppress senescence and induce angiogenesis in human and mouse endothelial cells. Blood 2013;121:3997-4006.
40 Wang K, Zhang S, Weber J, Baxter D, Galas DJ: Export of microRNAs and microRNAprotective protein by mammalian cells. $\mathrm{Nu}-$ cleic Acids Res 2010;38:7248-7259.

41 Xin H, Li Y, Buller B, Katakowski M, Zhang Y,Wang X, Shang X, Zhang ZG, Chopp M: Exosome-mediated transfer of miR-133b from multipotent mesenchymal stromal cells to neural cells contributes to neurite outgrowth. Stem Cells 2012;30:1556-1564.

42 Chairoungdua A, Smith DL, Pochard P, Hull M, Caplan MJ: Exosome release of $\beta$-catenin: a novel mechanism that antagonizes signaling. J Cell Biol 2010;190:1079-1091.

43 Gross JC, Chaudhary V, Bartscherer K, Boutros M: Active Wnt proteins are secreted on exosomes. Nat Cell Biol 2012;14:10361045.

44 Koles K, Nunnari J, Korkut C, Barria R, Brewer C, Li Y, Leszyk J, Zhang B, Budnik V: Mechanism of evenness interrupted (Evi)-exosome release at synaptic moutons. J Biol Chem 2012;287:16820-16834.

45 Korkut C, Ataman B, Ramachandran P, Ashley J, Barria R, Gherbesi N, Budnik V: Transsynaptic transmission of vesicular Wnt signals through Evi/Wntless. Cell 2009;139:393404.

46 Agarwal A, Fanelli G, Letizia M, Tung SL, Boardman D, Lechler R, Lombardi G, Smyth LA: Regulatory T cell-derived exosomes: possible therapeutic and diagnostic tools in transplantation. Front Immunol 2014;5:555.

47 Bobrie A, Colombo M, Raposo G, Théry C: Exosome secretion: molecular mechanisms and roles in immune responses. Traffic 2011; 12:1659-1668.

48 Fernández-Messina L, Gutiérrez-Vázquez C, Rivas-García E, Sánchez-Madrid F, de la Fuente $\mathrm{H}$ : Immunomodulatory role of microRNAs transferred by extracellular vesicles. Biol Cell 2015;107:61-77.

49 Mittelbrunn M, Gutiérrez-Vázquez C, Villarroya-Beltri C, González S, Sánchez-Cabo F, González MÁ, Bernad A, Sánchez-Madrid F: Unidirectional transfer of microRNA-loaded exosomes from $\mathrm{T}$ cells to antigen-presenting cells. Nat Commun 2011;2:282.

50 Montecalvo A, Larregina AT, Shufesky WJ, Stolz DB, Sullivan ML, Karlsson JM, Baty CJ, Gibson GA, Erdos G, Wang Z, Milosevic J, Tkacheva OA, Divito SJ, Jordan R, LyonsWeiler J, Watkins SC, Morelli AE: Mechanism of transfer of functional microRNAs between mouse dendritic cells via exosomes. Blood 2012;119:756-766.

51 Martin RK, Badrooks KB, Henningsson F, Heyman B, Conrad DH: Antigen transfer from exosomes to dendritic cells as an explanation for the immune enhancement seen by IgE immune complexes. PLoS One 2014;9: e110609.

52 Fujita Y, Yoshioka Y, Ito S, Araya J, Kuwano $\mathrm{K}$, Ochiya T: Intercellular communication by extracellular vesicles and their microRNAs in asthma. Clin Ther 2014;36:873-881. 
53 Poliakov A, Spilman M, Dokland T, Amling CL, Mobley JA: Structural heterogeneity and protein composition of exosome-like vesicles (prostasomes) in human semen. Prostate 2009;69:159-167.

54 Jenjaroenpun P, Kremenska Y, Nair VM, Kremenskoy M, Joseph B, Kurochkin IV: Characterization of RNA in exosomes secreted by human breast cancer cell lines using nextgeneration sequencing. Peer J 2013;1:e201.

55 Nolte-'t Hoen ENM, Buermans HPJ, Waasdorp M, Stoorvogel W, Wauben MHM, 't Hoen PAC: Deep sequencing of RNA from immune cell-derived vesicles uncovers the selective incorporation of small non-coding RNA biotypes with potential regulatory functions. Nucleic Acids Res 2012;40:9272-9285.

56 Zhou H, Cheruvanky A, Hu X, Matsumoto T, Hiramatsu N, Cho ME, Berger A, Leelahavanichkul $A$, Doi $K$, Chawla LS, Illei GG, Kopp JB, Balow JE, Austin HA III, Yuen PST, Star RA: Urinary exosomal transcription factors, a new class of biomarkers for renal disease. Kidney Int 2008;74:613-621.

57 Ung TH, Madsen HJ, Hellwinkel JE, Lencioni AM, Graner MW: Exosome proteomics reveals transcriptional regulator proteins with potential to mediate downstream pathways. Cancer Sci 2014;105:1384-1392.

58 Okoye IS, Coomes SM, Pelly VS, Czieso S, Papayannopoulos V, Tolmachova $\mathrm{T}$, Seabra MC, Wilson MS: MicroRNA-containing Tregulatory-cell-derived exosomes suppress pathogenic T helper 1 cells. Immunity 2014; 41:89-103.

59 Skogberg G, Lundberg V, Berglund M, Gudmundsdottir J, Telemo E, Lindgren S, Ekwall O: Human thymic epithelial primary cells produce exosomes carrying tissue-restricted antigens. Immunol Cell Biol 2015;93:727734.

60 Wang GJ, Liu Y, Qin A, Shah SV, Deng Z-b, Xiang X, Cheng Z, Liu C, Wang J, Zhang L, Grizzle WE, Zhang HG: Thymus exosomeslike particles induce regulatory T cells. J Immunol 2008; 181:5242-5248.

61 Bretz NP, Ridinger J, Rupp A-K, Rimbach K, Keller S, Rupp C, Marme F, Umansky L, Umansky V, Eigenbrod T, Sammar M, Altevogt $\mathrm{P}$ : Body fluid exosomes promote secretion of inflammatory cytokines in monocytic cells via TLR signaling. J Biol Chem 2013;288: 36691-36702.

62 Johnson K, Chu J, Huang M, PowelL M, Villinger F, Bond V: Innate cytokines associate with exosomes in plasma of HIV-1+ individuals (P6205). J Immunol 2013;190:118.26.

63 Konadu KA, Chu J, Huang MB, Amancha PK, Armstrong W, Powell MD, Villinger F, Bond VC: Association of cytokines with exosomes in the plasma of HIV-1-seropositive individuals. J Infect Dis 2015;211:1712-1716.
64 Sampey GC, Saifuddin M, Schwab A, Barclay R, Punya S, Chung M-C, Hakami RM, Asad Zadeh M, Lepene B, Klase ZA, El-Hage N, Young M, Iordanskiy S, Kashanchi F: Exosomes from HIV-1-infected cells stimulate production of pro-inflammatory cytokines through trans-activating response (TAR) RNA. J Biol Chem 2016;291:1251-1266.

65 Cossetti C, Iraci N, Mercer TR, Leonardi T, Alpi E, Drago D, Alfaro-Cervello C, Saini HK, Davis MP, Schaeffer J, Vega B, Stefanini M, Zhao CJ, Muller W, Garcia-Verdugo JM, Mathivanan S, Bachi A, Enright AJ, Mattick JS, Pluchino S: Extracellular vesicles from neural stem cells transfer IFN- $\gamma$ via Ifngr1 to activate Stat1 signaling in target cells. Mol Cell 2014;56:193-204.

66 Shefler I, Pasmanik-Chor M, Kidron D, Mekori YA, Hershko AY: T cell-derived microvesicles induce mast cell production of IL24: relevance to inflammatory skin diseases. J Allergy Clin Immunol 2014;133:217-224.e3.

67 Shefler I, Salamon P, Reshef T, Mor A, Mekori YA: T cell-induced mast cell activation: a role for microparticles released from activated T cells. J Immunol 2010;85:4206-4212.

68 Thery C, Duban L, Segura E, Veron P, Lantz $\mathrm{O}$, Amigorena $\mathrm{S}$ : Indirect activation of naive $\mathrm{CD} 4+\mathrm{T}$ cells by dendritic cell-derived exosomes. Nat Immunol 2002;3:1156-1162.

69 Admyre C, Grunewald J, Thyberg J, Gripenback S, Tornling G, Eklund A, Scheynius A, Gabrielsson S: Exosomes with major histocompatibility complex class II and co-stimulatory molecules are present in human BAL fluid. Eur Respir J 2003;22:578-583.

70 Skokos D, Botros HG, Demeure C, Morin J, Peronet R, Birkenmeier G, Boudaly S, Mécheri $S$ : Mast cell-derived exosomes induce phenotypic and functional maturation of dendritic cells and elicit specific immune responses in vivo. J Immunol 2003;170:3037-3045.

71 Skokos D, Le Panse S, Villa I, Rousselle JC, Peronet R, David B, Namane A, Mécheri S: Mast cell-dependent $B$ and T lymphocyte activation is mediated by the secretion of immunologically active exosomes. J Immunol 2001;166:868-876.

72 Skokos D, Le Panse S, Villa I, Rousselle JC, Peronet R, Namane A, David B, Mécheri S: Nonspecific B and T cell-stimulatory activity mediated by mast cells is associated with exosomes. Int Arch Allergy Immunol 2001;124: 133-136.

73 Al-Nedawi K, Szemraj J, Cierniewski CS Mast cell-derived exosomes activate endothelial cells to secrete plasminogen activator inhibitor type 1. Arterioscler Thromb Vasc Biol 2005;25:1744-1749.

74 Ekström K, Valadi H, Sjöstrand M, Malmhäll C, Bossios A, Eldh M, Lötvall J: Characterization of mRNA and microRNA in human mast cell-derived exosomes and their transfer to other mast cells and blood CD34 progenitor cells. J Extracell Vesicles 2012;16:1.
75 Wahlgren J, Karlson TDL, Glader P, Telemo E, Valadi H: Activated human T cells secrete exosomes that participate in IL-2 mediated immune response signaling. PLoS One 2012; 7:e49723.

76 Kulshreshtha A, Ahmad T, Agrawal A, Ghosh B: Proinflammatory role of epithelial cell-derived exosomes in allergic airway inflammation. J Allergy Clin Immunol 2012;131:11941203.e14.

77 Xia YC, Harris T, Stewart AG, Mackay GA: Secreted factors from human mast cells trigger inflammatory cytokine production by human airway smooth muscle cells. Int Arch Allergy Immunol 2013;160:75-85.

78 Mazzeo C, Canas JA, Zafra MP, Rojas Marco A, Fernandez-Nieto M, Sanz V, Mittelbrunn M, Izquierdo M, Baixaulli F, Sastre J, Del Pozo V: Exosome secretion by eosinophils: a possible role in asthma pathogenesis. J Allergy Clin Immunol 2015;135:1603-1613.

79 Clayton A, Court J, Navabi H, Adams M, Mason MD, Hobot JA, Newman GR, Jasani B: Analysis of antigen presenting cell derived exosomes, based on immuno-magnetic isolation and flow cytometry. J Immunol Methods 2001;247:163-174.

80 Raposo G, Nijman HW, Stoorvogel W, Liejendekker R, Harding CV, Melief CJ, Geuze HJ: B lymphocytes secrete antigen-presenting vesicles. J Exp Med 1996;183:1161-1172.

81 Sobo-Vujanovic A, Munich S, Vujanovic NL: Dendritic-cell exosomes cross-present Tolllike receptor-ligands and activate bystander dendritic cells. Cell Immunol 2014;289:119127.

82 Qazi KR, Gehrmann U, Domange Jordo E, Karlsson MC, Gabrielsson S: Antigen-loaded exosomes alone induce Th1-type memory through a B-cell-dependent mechanism. Blood 2009;113:2673-2683.

83 Vincent-Schneider H, Stumptner-Cuvelette P, Lankar D, Pain S, Raposo G, Benaroch P, Bonnerot C: Exosomes bearing HLA DR1 molecules need dendritic cells to efficiently stimulate specific T cells. Int Immunol 2002; 14:713-722.

84 Carroll-Portillo A, Surviladze Z, Cambi A, Lidke DS, Wilson BS: Mast cell synapses and exosomes: membrane contacts for information exchange. Front Immunol 2012;3:46.

85 Gaudenzio N, Espagnolle N, Mars LT, Liblau R, Valitutti S, Espinosa E: Cell-cell cooperation at the T helper cell/mast cell immunological synapse. Blood 2009;114:4979-4988.

86 Ramachandran S, Palanisamy V: Horizontal transfer of RNAs: exosomes as mediators of intercellular communication. Wiley Interdiscip Rev RNA 2012;3:286-293.

87 Gong J, Yang NS, Croft M, Weng IC, Sun L, Liu FT, Chen SS: The antigen presentation function of bone marrow-derived mast cells is spatiotemporally restricted to a subset expressing high levels of cell surface FceRI and MHC II. BMC Immunol 2010;11:34. 
88 Beauvillain C, Juste MO, Dion S, Pierre J, Dimier-Poisson I: Exosomes are an effective vaccine against congenital toxoplasmosis in mice. Vaccine 2009;27:1750-1757.

89 Schorey JS, Cheng Y, Singh PP, Smith VL: Exosomes and other extracellular vesicles in host-pathogen interactions. EMBO Rep 2015; 16:24-43.

90 Pitt JM, Charrier M, Viaud S, André F, Besse B, Chaput N, Zitvogel L: Dendritic cell-derived exosomes as immunotherapies in the fight against cancer. J Immunol 2014;193: 1006-1011.

91 Vermeij R, Leffers N, van der Burg SH, Melief CJ, Daemen T, Nijman HW: Immunological and clinical effects of vaccines targeting p53overexpressing malignancies. J Biomed Biotechnol 2011;2011:702146.

92 Viaud S, Théry C, Ploix S, Tursz T, Lapierre V, Lantz O, Zitvogel L, Chaput N: Dendritic cell-derived exosomes for cancer immunotherapy: what's next? Cancer Res 2010;70: 1281-1285.

93 Admyre C, Bohle B, Johansson SM, FockeTejkl M, Valenta R, Scheynius A, Gabrielsson $S$ : B cell-derived exosomes can present allergen peptides and activate allergen-specific $\mathrm{T}$ cells to proliferate and produce $\mathrm{T}_{\mathrm{H}}$-like cytokines. J Allergy Clin Immunol 2007;120: 1418-1424.

94 Suojalehto H, Lindström I, Majuri ML, Mitts C, Karjalainen J, Wolff H, Alenius H: Altered microRNA expression of nasal mucosa in long-term asthma and allergic rhinitis. Int Arch Allergy Immunol 2014;163:168-178.

95 Wu G, Yang G, Zhang R, Xu G, Zhang L, Wen W, Lu J, Liu J, Yu Y: Altered microRNA expression profiles of extracellular vesicles in nasal mucus from patients with allergic rhinitis. Allergy Asthma Immunol Res 2015;7: 449-457.

96 Shin SH, Park JY, Jeon CH, Choi JK, Lee SH: Quantitative analysis of eotaxin and RANTES messenger RNA in nasal polyps: association of tissue and nasal eosinophils. Laryngoscope 2000;110:1353-1357.

97 Qiu S, Du Y, Duan X, Geng X, Xie J, Gao H, Yang PC: Cytotoxic T lymphocytes mediate chronic inflammation of the nasal mucosa of patients with atypical allergic rhinitis. N Am J Med Sci 2011;3:378-383.

98 Lässer C, O’Neil SE, Shelke GV, Sihlbom C, Hansson SF, Gho YS, Lundbäck B, Lötvall J: Exosomes in the nose induce immune cell trafficking and harbour an altered protein cargo in chronic airway inflammation. J Transl Med 2016;14:181.

99 Ptak W, Geba GP, Askenase PW: Initiation of delayed-type hypersensitivity by low doses of monoclonal IgE antibody: mediation by serotonin and inhibition by histamine. J Immunol 1991;146:3929-3936.
100 Zhang L, Hou D, Chen X, Li D, Zhu L, Zhang Y, Li J, Bian Z, Liang X, Cai X, Yin Y, Wang C, Zhang T, Zhu D, Zhang D, Xu J, Chen Q, Ba Y, Liu J, Wang Q, Chen J, Wang J, Wang M, Zhang Q, Zhang J, Zen K, Zhang CY: Exogenous plant MIR168a specifically targets mammalian LDLRAP1: evidence of crosskingdom regulation by microRNA. Cell Res 2012;22:107-126.

101 Prado N, Alché Jde D, Casado-Vela J, Mas S, Villalba M, Rodríguez R, Batanero E: Nanovesicles are secreted during pollen germination and pollen tube growth: a possible role in fertilization. Mol Plant 2014;7:573-577.

102 Wei T, Hibino H, Omura T: Release of Rice $d$ warf virus from insect vector cells involves secretory exosomes derived from multivesicular bodies. Commun Integr Biol 2009;2: 324-326.

103 Vallhov H, Gutzeit C, Hultenby K, Valenta R, Gronlund H, Scheynius A: Dendritic cellderived exosomes carry the major cat allergen Fel $\mathrm{d} 1$ and induce an allergic immune response. Allergy 2015;70:1651-1655.

104 Luo X, Han M, Liu J, Wang Y, Luo X, Zheng J, Wang S, Liu Z, Liu D, Yang PC, Li H: Epithelial cell-derived micro RNA-146a generates interleukin-10-producing monocytes to inhibit nasal allergy. Sci Rep 2015;5:15937.

105 Platts-Mills TA, Vaughan JW, Blumenthal K, Woodfolk JA, Sporik RB: Decreased prevalence of asthma among children with high exposure to cat allergen: relevance of the modified Th2 response. Mediators Inflamm 2001;10:288-291.

106 Akdis CA, Akdis M: Mechanisms of allergen-specific immunotherapy and immune tolerance to allergens. World Allergy Organ J 2015;8:17.

107 Gehrmann U, Hiltbrunner S, Georgoudaki AM, Karlsson MC, Näslund TI, Gabrielsson S: Synergistic induction of adaptive antitumor immunity by co-delivery of antigen with a-galactosylceramide on exosomes. Cancer Res 2013;73:3865-3876.

108 Campos RA, Szczepanik M, Itakura A, Akahira-Azuma M, Sidobre S, Kronenberg M, Askenase PW: Cutaneous immunization rapidly activates liver invariant Va14 NKT cells stimulating B-1 B cells to initiate T cell recruitment for elicitation of contact sensitivity. J Exp Med 2003;198:1785-1796.

109 Yamamoto N, Kerfoot SM, Hutchinson AT, Dela Cruz CS, Nakazawa N, Szczepanik M, Majewska-Szczepanik M, Nazimek K, Ohana N, Bryniarski K, Mori T, Muramatsu M, Kanemitsu K, Askenase PW: Expression of activation-induced cytidine deaminase enhances the clearance of pneumococcal pneumonia: evidence of a subpopulation of protective anti-pneumococcal B1a cells. Immunology 2016;147:97113.

110 Prado N, De Linares C, Sanz ML, Gamboa P, Villalba M, Rodríguez R, Batanero E: Pollensomes as natural vehicles for pollen allergens. J Immunol 2015;195:445-449.
111 Gol J, Van Niel G, Lebreton C, Lepelletier Y, Candalh C, Dugave C, Heath JK, Raposo G, Cerf-Bensussan N, Heyman M: T84-intestinal epithelial exosomes bear MHC class II/ peptide complexes potentiating antigen presentation by dendritic cells. Gastroenterology 2007;132:1866-1876.

112 Sánchez-Gómez FJ, González-Morena JM, Vida Y, Pérez-Inestrosa E, Blanca M, Torres MJ, Pérez-Sala D: Amoxicillin haptenates intracellular proteins that can be transported in exosomes to target cells. Allergy DOI: 10.1111/all.12958.

113 Choi EB, Hong SW, Kim DK, Jeon SG, Kim KR, Cho SH, Gho YS, Jee YK, Kim YK: Decreased diversity of nasal microbiota and their secreted extracellular vesicles in patients with chronic rhinosinusitis based on a metagenomic analysis. Allergy 2014;69:517526.

114 Buck AH, Coakley G, Simbari F, McSorley HJ, Quintana JF, Le Bihan T, Kumar S, Abreu-Goodger C, Lear M, Harcus Y, Ceroni A, Babayan SA, Blaxter $M$, Ivens A, Maizels RM: Exosomes secreted by nematode parasites transfer small RNAs to mammalian cells and modulate innate immunity. Nat Commun 2014;5:5488.

115 Marcilla A, Trelis M, Cortés A, Sotillo J, Cantalapiedra F, Minguez MT, Valero ML, Sánchez del Pino MM, Muñoz-Antoli C, Toledo R, Bernal D: Extracellular vesicles from parasitic helminths contain specific excretory/secretory proteins and are internalized in intestinal host cells. PLoS One 2012; 7:e45974.

116 Siles-Lucas M, Morchon R, Simon F, Manzano-Roman R: Exosome-transported microRNAs of helminth origin: new tools for allergic and autoimmune diseases therapy? Parasite Immunol 2015;37:208-214.

117 Atayde VD, Aslan H, Townsend S, Hassani K, Kamhawi S, Olivier M: Exosome secretion by the parasitic protozoan Leishmania within the sand fly midgut. Cell Rep 2015;13: 957-967.

118 Silverman JM, Clos J, Horakova E, Wang AY, Wiesgigl M, Kelly I, Lynn MA, McMaster WR, Foster LJ, Levings MK, Reiner NE: Leishmania exosomes modulate innate and adaptive immune responses through effects on monocytes and dendritic cells. J Immunol 2010;185:5011-5022.

119 Trocoli Torrecilhas AC, Tonelli RR, Pavanelli WR, da Silva JS, Schumacher RI, de Souza W, Cunha E Silva N, de Almeida Abrahamsohn I, Colli W, Manso Alves MJ: Trypanosoma cruzi: parasite shed vesicles increase heart parasitism and generate an intense inflammatory response. Microbes Infect 2009;11:29-39.

120 Twu O, de Miguel N, Lustig G, Stevens GC, Vashisht AA, Wohlschlegel JA, Johnson PJ: Trichomonas vaginalis exosomes deliver cargo to host cells and mediate host:parasite interactions. PLoS Pathog 2013;9:e1003482. 
121 Costa-Silva B, Aiello NM, Ocean AJ, Singh S, Zhang H, Thakur BK, Becker A, Hoshino A, Mark MT, Molina H, Xiang J, Zhang T, Theilen TM, García-Santos G, Williams C, Ararso Y, Huang Y, Rodrigues G, Shen TL, Labori KJ, Lothe IM, Kure EH, Hernandez J, Doussot A, Ebbesen SH, Grandgenett PM, Hollingsworth MA, Jain M, Mallya K, Batra SK, Jarnagin WR, Schwartz RE, Matei I, Peinado $\mathrm{H}$, Stanger BZ, Bromberg J, Lyden D: Pancreatic exosomes initiate pre-metastatic niche formation in the liver. Nat Cell Biol 2015;17:816-826.

122 Peinado H, Alečković M, Lavotshkin S, Matei I, Costa-Silva B, Moreno-Bueno G, Hergueta-Redondo M, Williams C, García-Santos G, Ghajar C, Nitadori-Hoshino A, Hoffman C, Badal K, Garcia BA, Callahan MK, Yuan J, Martins VR, Skog J, Kaplan RN, Brady MS, Wolchok JD, Chapman PB, Kang Y, Bromberg J, Lyden D: Melanoma exosomes educate bone marrow progenitor cells toward a pro-metastatic phenotype through MET. Nat Med 2012;18:883-891.

123 Hoshino A, Costa-Silva B, Shen TL, Rodrigues G, Hashimoto A, Tesic Mark M, et al: Tumour exosome integrins determine organotropic metastasis. Nature 2015;527:329-335.

124 Chung KF: Cytokines as targets in chronic obstructive pulmonary disease. Curr Drug Targets 2006;7:675-681.

125 Park JA, Sharif AS, Tschumperlin DJ, Lau L, Limbrey R, Howarth P, Drazen JM: Tissue factor-bearing exosome secretion from human mechanically stimulated bronchial epithelial cells in vitro and in vivo. J Allergy Clin Immunol 2012;130:1375-1383.

126 Vargas A, Lavoie J-P: Neutrophil-derived exosomes: a new mechanism possibly contributing to airway smooth muscle remodeling. Am J Respir Crit Care Med 2015;191:A6475.

127 Torregrosa Paredes P, Esser J, Admyre C, Nord M, Rahman QK, Lukic A, Radmark O, Gronneberg R, Grunewald J, Eklund A, Scheynius A, Gabrielsson S: Bronchoalveolar lavage fluid exosomes contribute to cytokine and leukotriene production in allergic asthma. Allergy 2012;67:911-919.

128 Kosaka N, Iguchi H, Hagiwara K, Yoshioka Y, Takeshita F, Ochiya T: Neutral sphingomyelinase 2 (nSMase2)-dependent exosomal transfer of angiogenic microRNAs regulate cancer cell metastasis. J Biol Chem 2013; 288:10849-10859.

129 Singh R, Pochampally R, Watabe K, Lu Z, Mo YY: Exosome-mediated transfer of miR$10 \mathrm{~b}$ promotes cell invasion in breast cancer. Mol Cancer 2014;13:256.

130 Yuyama K, Sun H, Sakai S, Mitsutake S, Okada M, Tahara H, Furukawa J, Fujitani N, Shinohara Y, Igarashi Y: Decreased amyloid- $\beta$ pathologies by intracerebral loading of glycosphingolipid-enriched exosomes in Alzheimer model mice. J Biol Chem 2014; 289:24488-24498.
131 Yang W, Schmid E, Nurbaeva MK, Szteyn K, Leibrock C, Yan J, Schaller M, Gulbins E, Shumilina E, Lang F: Role of acid sphingomyelinase in the regulation of mast cell function. Clin Exp Allergy 2014;44:79-90.

132 Mattes J, Collison A, Plank M, Phipps S, Foster PS: Antagonism of microRNA-126 suppresses the effector function of $\mathrm{TH} 2$ cells and the development of allergic airways disease. Proc Natl Acad Sci USA 2009;4:1870418709.

133 Plank MW, Maltby S, Tay HL, Stewart J, Eyers F, Hansbro PM, Foster PS: MicroRNA expression is altered in an ovalbumin-induced asthma model and targeting miR-155 with antagomirs reveals cellular specificity. PLoS One 2015;10:e144810.

134 Canas JA, Mazzeo C, Guerra A, Barranco P, Quirce S, Ruiz Hornillos J, Izquierdo M, Sastre J, del Pozo V: Exosomes from eosinophils of asthmatic patients produce functional alterations on structural lung cell. EAACI Online Library 2015;98145.

135 Del Pozo V, Mazzeo C, Rodriguez Marco A, Fernandez-Nieto MDM, Paz Zafra M, Sanz V, Sastre J: Exosomes secretion by eosinophils: a possible role in asthma pathogenesis. J Allergy Clin Immunol 2014;133(suppl): AB58.

136 Mahmudi-Azer S, Downey GP, Moqbel R: Translocation of the tetraspanin CD63 in association with human eosinophil mediator release. Blood 2002;99:4039-4047.

137 Kumar M, Ahmad T, Sharma A, Mabalirajan U, Kulshreshtha A, Agrawal A, Ghosh B: Let-7 microRNA-mediated regulation of IL13 and allergic airway inflammation. J Allergy Clin Immunol 2011;128:1077-1085. e10.

138 Esser J, Gehrmann U, D’Alexandri FL, Hidalgo-Estevez AM, Wheelock CE, Scheynius A, Gabrielsson S, Radmark O: Exosomes from human macrophages and dendritic cells contain enzymes for leukotriene biosynthesis and promote granulocyte migration. J Allergy Clin Immunol 2010;126: 1032-1040.

139 Majumdar R, Tavakoli Tameh A, Parent CA: Exosomes mediate $\mathrm{LTB}_{4}$ release during neutrophil chemotaxis. PLoS Biol 2016;14: e1002336.

140 Sadik CD, Luster AD: Lipid-cytokine-chemokine cascades orchestrate leukocyte recruitment in inflammation. J Leukoc Biol 2012;91:207-215.

141 Reutershan J, Basit A, Galkina EV, Ley K: Sequential recruitment of neutrophils into lung and bronchoalveolar lavage fluid in LPS-induced acute lung injury. Am J Physiol Lung Cell Mol Physiol 2005;289:L807-L815.

142 Peters M, Kauth M, Schwarze J, KörnerRettberg C, Riedler J, Nowak D, BraunFahrländer C, von Mutius E, Bufe A, Holst O: Inhalation of stable dust extract prevents allergen induced airway inflammation and hyperresponsiveness. Thorax 2006;61:134139.
143 Schuijs MJ, Willart MA, Vergote K, Gras D, Deswarte K, Ege MJ, Madeira FB, Beyaert R, van Loo G, Bracher F, von Mutius E, Chanez P, Lambrecht BN, Hammad H: Farm dust and endotoxin protect against allergy through A20 induction in lung epithelial cells. Science 2015;349:1106-1110.

144 Kim YS, Choi EJ, Lee WH, Choi SJ, Roh TY, Park J, Jee YK, Zhu Z, Koh YY, Gho YS, Kim YK: Extracellular vesicles, especially derived from Gram-negative bacteria, in indoor dust induce neutrophilic pulmonary inflammation associated with both Th1 and Th17 cell responses. Clin Exp Allergy 2013;43:443454.

145 Choy DF, Hart KM, Borthwick LA, Shikotra A, Nagarkar DR, Siddiqui S, Jia G, Ohri CM, Doran E, Vannella KM, Butler CA, Hargadon B, Sciurba JC, Gieseck RL, Thompson RW, White S, Abbas AR, Jackman J, Wu LC, Egen JG, Heaney LG, Ramalingam TR, Arron JR, Wynn TA, Bradding P: TH2 and TH17 inflammatory pathways are reciprocally regulated in asthma. Sci Transl Med 2015;7:301ra129.

146 Peng X, Hassoun PM, Sammani S, McVerry BJ, Burne MJ, Rabb H, Pearse D, Tuder RM, Garcia JGN: Protective effects of sphingosine 1-phosphate in murine endotoxin-induced inflammatory lung injury. Am J Respir Crit Care Med 2004;169:1245-1251.

147 Kajimoto T, Okada T, Miya S, Zhang L, Nakamura S: Ongoing activation of sphingosine 1-phosphate receptors mediates maturation of exosomal multivesicular endosomes. Nat Commun 2013;4:2712.

148 Dinkins MB, Dasgupta S, Wang G, Zhu G, Bieberich E: Exosome reduction in vivo is associated with lower amyloid plaque load in the 5XFAD mouse model of Alzheimer's disease. Neurobiol Aging 2014;35:17921800.

149 Kim MR, Hong SW, Choi EB, Lee WH, Kim YS, Jeon SG, Jang MH, Gho YS, Kim YK: Staphylococcus aureus-derived extracellular vesicles induce neutrophilic pulmonary inflammation via both Th1 and Th17 cell responses. Allergy 2012;67:1271-1281.

150 Rebane A, Akdis CA: MicroRNAs in allergy and asthma. Curr Allergy Asthma Rep 2014; $14: 424$.

151 Levanen B, Bhakta NR, Torregrosa Paredes P, Barbeau R, Hiltbrunner S, Pollack JL, Skold CM, Svartengren M, Grunewald J, Gabrielsson S, Eklund A, Larsson BM, Woodruff PG, Erle DJ, Wheelock AM: Altered microRNA profiles in bronchoalveolar lavage fluid exosomes in asthmatic patients. J Allergy Clin Immunol 2013;131:894-903.

152 Solberg OD, Ostrin EJ, Love MI, Peng JC, Bhakta NR, Hou L, Nguyen C, Solon M, Nguyen C, Barczak AJ, Zlock LT, Blagev DP, Finkbeiner WE, Ansel KM, Arron JR, Erle DJ, Woodruff PG: Airway epithelial miRNA expression is altered in asthma. Am J Respir Crit Care Med 2012;186:965-974. 
153 Maruoka S, Gon Y, Shikano S, Shintani Y, Koyama D, Sekiyama T, Hiranuma H, Inoue T, Takeshita I, Tsuboi E, Soda K, Hashimoto S: Exosomal MicroRNAs in the serum are potential real-time biomarkers for allergic inflammation in the airway of mice (American Thoracic Society International Conference abstracts). Am J Respir Crit Care Med 2014;189:A4211.

154 Pinkerton M, Chinchilli V, Banta E, Craig T, August A, Bascom R, Cantorna M, Harvill E, Ishmael FT: Differential expression of microRNAs in exhaled breath condensates of patients with asthma, patients with chronic obstructive pulmonary disease, and healthy adults. J Allergy Clin Immunol 2013;132: 217-219.

155 Sinha A, Yadav AK, Chakraborty S, Kabra SK, Lodha R, Kumar M, Kulshreshtha A, Sethi T, Pandey R, Malik G, Laddha S, Mukhopadhyay A, Dash D, Ghosh B, Agrawal A: Exosome-enclosed microRNAs in exhaled breath hold potential for biomarker discovery in patients with pulmonary diseases. J Allergy Clin Immunol 2013;132:219-222.

156 Arroyo JD, Chevillet JR, Kroh EM, Ruf IK, Pritchard CC, Gibson DF, Mitchell PS, Bennett CF, Pogosova-Agadjanyan EL, Stirewalt DL, Tait JF, Tewari M: Argonaute2 complexes carry a population of circulating microRNAs independent of vesicles in human plasma. Proc Natl Acad Sci USA 2011;108: 5003-5008.

157 Kurchinovich A, Burwinkel B: Distinct AGO1 and AGO2 associated miRNA profiles in human cells and blood plasma. RNA Biol 2012;9:1066-1075.

158 Li L, Zhu D, Huang L, Zhang J, Bian Z, Chen X, Liu Y, Zhang CY, Zen K: Argonaute 2 complexes selectively protect the circulating microRNAs in cell-secreted microvesicles. PLoS One 2012;7:e46957.

159 Turchinovich A, Weiz L, Langheinz A, Burwinkel B: Characterization of extracellular circulating microRNA. Nucleic Acids Res 2011;39:7223-7233.

160 Prado N, Marazuela EG, Segura E, Fernandez-Garcia H, Villalba M, Thery C, Rodriguez R, Batanero E: Exosomes from bronchoalveolar fluid of tolerized mice prevent allergic reaction. J Immunol 2008;181:15191525.

161 Karlsson M, Lundin S, Dahlgren U, Kahu H, Pettersson I, Telemo E: 'Tolerosomes' are produced by intestinal epithelial cells. Eur J Immunol 2001;31:2892-2900.

162 Lonnqvist A, Ostman S, Almqvist N, Hultkrantz S, Telemo E, Wold AE, Rask C: Neonatal exposure to staphylococcal superantigen improves induction of oral tolerance in a mouse model of airway allergy. Eur J Immunol 2009;39:447-456.

Exosomes in Allergy and Hypersensitivity
163 van Niel G, Mallegol J, Bevilacqua C, Candalh $\mathrm{C}$, Brugière $\mathrm{S}$, Tomaskovic-Crook $\mathrm{E}$, Heath JK, Cerf-Bensussan N, Heyman M: Intestinal epithelial exosomes carry MHC class II/peptides able to inform the immune system in mice. Gut 2003;52:1690-1697.

164 Admyre C, Johansson SM, Qazi KR, Filén JJ, Lahesmaa R, Norman M, Neve EP, Scheynius A, Gabrielsson S: Exosomes with immune modulatory features are present in human breast milk. J Immunol 2007;179:19691978.

165 Zhou Q, Li M, Wang X, Li Q, Wang T, Zhu Q, Zhou X, Wang X, Gao X, Li X: Immunerelated MicroRNAs are abundant in breast milk exosomes. Int J Biol Sci 2012;8:118123.

166 Izumi H, Kosaka N, Shimizu T, Sekine K, Ochiya T, Takase M: Bovine milk contains microRNA and messenger RNA that are stable under degradative conditions. J Dairy Sci 2012;95:4831-4841.

167 Gu Y, Li M, Wang T, Liang Y, Zhong Z, Wang X, Zhou Q, Chen L, Lang Q, He Z, Chen X, Gong J, Gao X, Li X, Lv X: Lactation-related MicroRNA expression profiles of porcine breast milk exosomes. PLoS One 2012;7:e43691.

168 Sun Q, Chen X, Yu J, Zen K, Zhang CY, Li L: Immune modulatory function of abundant immune-related microRNAs in microvesicles from bovine colostrum. Protein Cell 2013;4:197-210.

169 Parigi SM, Eldh M, Larssen P, Gabrielsson S, Villablanca EJ: Breast milk and solid food shaping intestinal immunity. Front Immunol 2015;6:415.

170 Pieters BC, Arntz OJ, Bennink MB, Broeren MG, van Caam AP, Koenders MI, van Lent PL, van den Berg WB, de Vries M, van der Kraan PM, van de Loo FA: Commercial cow milk contains physically stable extracellular vesicles expressing immunoregulatory TGF- $\beta$. PLoS One 2015;10:e0121123.

171 Melnik BC, John SM, Schmitz G: Milk: An exosomal microRNA transmitter promoting thymic regulatory $\mathrm{T}$ cell maturation preventing the development of atopy? J Transl Med 2014;12:43.

172 Izumi H, Tsuda M, Sato Y, Kosaka N, Ochiya T, Iwamoto H, Namba K, Takeda Y: Bovine milk exosomes contain microRNA and mRNA and are taken up by human macrophages. J Dairy Sci 2015;98:2920-2933.

173 Li QJ, Chau J, Ebert PJ, Sylvester G, Min H, Liu G, Braich R, Manoharan M, Soutschek J, Skare P, Klein LO, Davis MM, Chen CZ: miR-181a is an intrinsic modulator of T cell sensitivity and selection. Cell 2007;129:147161.

174 Momen-Heravi F, Bala S, Bukong T, Szabo G: Exosome-mediated delivery of functionally active miRNA-155 inhibitor to macrophages. Nanomedicine 2014;10:1517-1527.
175 Torregrosa Paredes P, Gutzeit C, Johansson S, Admyre C, Stenius F, Alm J, Scheynius A, Gabrielsson S: Differences in exosome populations in human breast milk in relation to allergic sensitization and lifestyle. Allergy 2014;69:463-471.

176 Arntz OJ, Pieters BC, Oliveira MC, Broeren MG, Bennink MB, de Vries M, van Lent PL, Koenders MI, van den Berg WB, van der Kraan PM, van de Loo FA: Oral administration of bovine milk derived extracellular vesicles attenuates arthritis in two mouse models. Mol Nutr Food Res 2015;59:1701-1712.

177 Kim JH, Jeun EJ, Hong CP, Kim SH, Jang MS, Lee EJ, Moon SJ, Yun CH, Im SH, Jeong SG, Park BY, Kim KT, Seoh JY, Kim YK, Oh SJ, Ham JS, Yang BG, Jang MH: Extracellular vesicle-derived protein from Bifidobacterium longum alleviates food allergy through mast cell suppression. J Allergy Clin Immunol 2016;137:507-516.e8.

178 Chu H, Khosravi A, Kusumawardhani IP, Kwon AH, Vasconcelos AC, Cunha LD, Mayer AE, Shen Y, Wu WL, Kambal A, Targan SR, Xavier RJ, Ernst PB, Green DR, McGovern DP, Virgin HW, Mazmanian SK: Gene-microbiota interactions contribute to the pathogenesis of inflammatory bowel disease. Science 2016;352:1116-1120.

179 Cheng Y, Schorey JS: Exosomes carrying mycobacterial antigens can protect mice against Mycobacterium tuberculosis infection. Eur J Immunol 2013;43:3279-3290.

180 Alexander M, Hu R, Runtsch MC, Kagele DA, Mosbruger TL, Tolmachova T, Seabra MC, Round JL, Ward DM, O'Connell RM: Exosome-delivered microRNAs modulate the inflammatory response to endotoxin. Nat Commun 2015;6:7321.

181 Aline F, Bout D, Amigorena S, Roingeard P, Dimier-Poisson I: Toxoplasma gondii antigen-pulsed-dendritic cell-derived exosomes induce a protective immune response against $T$. gondii infection. Infect Immunol 2004;72:4127-4137.

182 Kim OY, Hong BS, Park KS, Yoon YJ, Choi SJ, Lee WH, Roh TY, Lötvall J, Kim YK, Gho YS: Immunization with Escherichia coli outer membrane vesicles protects bacteria-induced lethality via Th1 and Th17 cell responses. J Immunol 2013;190:4092-4102.

183 Kim SH, Bianco N, Menon R, Lechman ER, Shufesky WJ, Morelli AE, Robbins PD: Exosomes derived from genetically modified DC expressing FasL are anti-inflammatory and immunosuppressive. Mol Ther 2006;13: 289-300.

184 Kim SH, Bianco NR, Shufesky WJ, Morelli AE, Robbins PD: Effective treatment of inflammatory disease models with exosomes derived from dendritic cells genetically modified to express IL-4. J Immunol 2007; 179:2242-2249. 
185 Ruffner MA, Kim SH, Bianco NR, Francisco LM, Sharpe AH, Robbins PD: B7-1/2, but not PD-L1/2 molecules, are required on IL10-treated tolerogenic DC and DC-derived exosomes for in vivo function. Eur J Immunol 2009;39:3084-3090.

186 Kim SH, Lechman ER, Bianco N, Menon R, Keravala A, Nash J, Mi Z, Watkins SC, Gambotto A, Robbins PD: Exosomes derived from IL-10-treated dendritic cells can suppress inflammation and collagen-induced arthritis. J Immunol 2005;174:6440-6448.

187 Bianco NR, Kim SH, Ruffner MA, Robbins PD: Therapeutic effect of exosomes from indoleamine 2,3-dioxygenase-positive dendritic cells in collagen-induced arthritis and delayed-type hypersensitivity disease models. Arthritis Rheum 2009;60:380-389.

188 Karlsson MR, Kahu H, Hanson LA, Telemo E, Dahlgren UI: An established immune response against ovalbumin is suppressed by a transferable serum factor produced after ovalbumin feeding: a role of CD25+ regulatory cells. Scand J Immunol 2002;55:470-477.

189 Karlsson MR, Kahu H, Hanson LA, Telemo E, Dahlgren UI: Tolerance and bystander suppression, with involvement of CD25positive cells, is induced in rats receiving serum from ovalbumin-fed donors. Immunology 2000;100:326-333.

190 Yang C, Kim SH, Bianco NR, Robbins PD: Tumor-derived exosomes confer antigenspecific immunosuppression in a murine delayed-type hypersensitivity model. PLoS One 2011;6:e22517.

191 Kim SH, Bianco NR, Shufesky WJ, Morelli AE, Robbins PD: MHC class II+ exosomes in plasma suppress inflammation in an antigen-specific and Fas ligand/Fas-dependent manner. J Immunol. 2007;179:2235-2241.

192 Ptak W, Nazimek K, Askenase PW, Bryniarski K: From mysterious supernatant entity to miRNA-150 in antigen-specific exosomes: a history of hapten-specific $\mathrm{T}$ suppressor factor. Arch Immunol Ther Exp 2015;63:345356.

193 Bryniarski K, Nazimek K, Martin E, Ptak M, Askenase PW, Ptak W: CD8+ T cell-derived exosomal miRNA-150 suppresses induction and effector phases of murine contact sensitivity as well as symptoms of active allergy. Centr Eur J Immunol 2014;39(suppl 1):20.

194 Dey N, Szczepanik M, Lau K, Majewska M Askenase P: Stimulatory lipids accumulate in the mouse liver within $30 \mathrm{~min}$ of contact sensitization to facilitate the activation of naive iNKT cells in a CD1d-dependent fashion. Scand J Immunol 2011;74:52-61.

195 Askenase PW, Bryniarski K, Paliwal V, Redegeld F, Groot Kormelink T, Kerfoot S, Hutchinson AT, van Loveren H, Campos R, Itakura A, Majewska-Szczepanik M, Yamamoto N, Nazimek K, Szczepanik M, Ptak W: A subset of AID-dependent B-1a cells initiates hypersensitivity and pneumococcal pneumonia resistance. Ann NY Acad Sci 2015;1362:200-214.

196 Kerfoot S, Szczepanik M, Tung J, Askenase P: Identification of initiator B-cells, a novel subset of activation induced deaminase-dependent B-1-like cells that mediate initiation of contact sensitivity. J Immunol 2008;181: 1717-1727.

197 Yang Y, Wang C, Yang Q, Kantor AB, Chu H, Ghosn EE, Qin G, Mazmanian SK, Han J, Herzenberg LA: Distinct mechanisms define murine B cell lineage immunoglobulin heavy chain $(\operatorname{IgH})$ repertoires. eLife 2015; 4:e09083.

198 Itakura A, Szczepanik M, Campos RA, Paliwal V, Majewska M, Matsuda H, Takatsu K, Askenase PW: An hour after immunization peritoneal B-1 cells are activated to migrate to lymphoid organs where within 1 day they produce IgM antibodies that initiate elicitation of contact sensitivity. J Immunol 2005; 175:7170-7178.

199 Askenase PW, Rosenstein RW, Ptak W: T cells produce an antigen binding factor with in vivo activity analogous to IgE antibody. J Exp Med 1983;157:862-873.

200 Geba GP, Wegner CD, Wolyniec WW, Li Y, Askenase PW: Nonatopic asthma: in vivo airway hyperreactivity adoptively transferred to naive mice by THY-1(+) and
B220(+) antigen-specific cells that lack surface expression of CD3. J Clin Invest 1997; 100:629-638.

201 Szczepanik M, Akahira-Azuma M, Bryniarski K, Tsuji RF, Kawikova I, Ptak W, Kiener C, Campos RA, Askenase PW: B-1 B cells mediate required early $\mathrm{T}$ cell recruitment to elicit protein-induced delayed-type hypersensitivity. J Immunol 2003;171:6225-6235.

202 Redegeld FA, van der Heijden MW, Kool M, Heijdra BM, Garssen J, Kraneveld AD, Van Loveren H, Roholl P, Saito T, Verbeek JS, Claassens J, Koster AS, Nijkamp FP: Immunoglobulin-free light chains elicit immediate hypersensitivity-like responses. Nat Med 2002;8:694-701.

203 Hutchinson AT, Jones DR, Raison RL: The ability to interact with cell membranes suggests possible biological roles for free light chain. Immunol Lett 2012;142:75-77.

204 Hutchinson AT, Ramsland PA, Jones DR, Agostino M, Lund ME, Jennings CV, Bockhorni V, Yuriev E, Edmundson AB, Raison RL: Free Ig light chains interact with sphingomyelin and are found on the surface of myeloma plasma cells in an aggregated form. J Immunol 2010;185:4179-4188.

205 Hutchinson AT, Malik A, Berkahn MB, Agostino M, To J, Tacchi JL, Djordjevic SP, Turnbull L, Whitchurch CB, Edmundson $\mathrm{AB}$, Jones DR, Raison RL, Ramsland PA: Formation of assemblies on cell membranes by secreted proteins: molecular studies of free $\lambda$ light chain aggregates found on the surface of myeloma cells. Biochem J 2013; 454:479-489.

206 Nazimek K, Ptak W, Nowak B, Ptak M, Askenase PW, Bryniarski K: Macrophages play an essential role in antigen-specific immune suppression mediated by T CD $8+$ cellderived exosomes. Immunology 2015;146: 23-32.

207 Nazimek K, Nowak B, Marcinkiewicz J, Ptak M, Ptak W, Bryniarski K: Enhanced generation of reactive oxygen intermediates by suppressor T cell-derived exosome-treated macrophages. Folia Med Cracov 2014;54: 37-52. 